\title{
Organic Production Systems in Northern Highbush Blueberry: I. Impact of Planting Method, Cultivar, Fertilizer, and Mulch on Yield and Fruit Quality from Planting through Maturity
}

\author{
Bernadine C. Strik ${ }^{\mathbf{1}}$ and Amanda Vance \\ Department of Horticulture, Oregon State University, 4017 ALS, Corvallis, OR 97331 \\ David R. Bryla \\ U.S. Department of Agriculture, Agricultural Research Service, Horticultural Crops Research Laboratory, $3420 \mathrm{NW}$ \\ Orchard Avenue, Corvallis, OR 97330
}

Dan M. Sullivan
Department of Crop and Soil Science, Oregon State University, 3045 ALS, Corvallis, OR 97331

Additional index words. fertilization, weed management, weed mat, compost, raised beds, Vaccinium corymbosum

Abstract. A long-term trial was established in Oct. 2006 in western Oregon to identify organic production systems for maximum yield and quality in highbush blueberry (Vaccinium corymbosum $\mathbf{L}$.). The planting was transitional during the first year after planting and was certified organic during fruit production (2008-16). Treatments included planting method (on raised beds or flat ground), fertilizer source (granular feather meal or fish solubles), and rate "“low" and "high" rates of 29 and $57 \mathrm{~kg} \cdot \mathrm{ha}^{-1} \mathrm{~N}$ during establishment, increased incrementally as the planting matured to 73 and $140 \mathrm{~kg} \cdot \mathrm{ha}^{-1} \mathrm{~N}$, respectively), mulch [sawdust, yard debris compost topped with sawdust (compost + sawdust), or black, woven polyethylene groundcover (weed mat)], and cultivar ('Duke' and 'Liberty'). Mulches were replenished, as needed, and weeds were controlled throughout the study. Raised beds resulted in greater yield than flat ground during the establishment years but had less effect on yield once the plants were mature. After 9 years, cumulative yield was $22 \%$ greater on raised beds than on flat ground in 'Liberty' but was unaffected by planting method in 'Duke'. Cumulative yield was also $10 \%$ greater with feather meal than with fish solubles, on average, and $4 \%$ greater with the low rate than with the high rate of fertilizer. 'Duke' was particularly sensitive to fertilizer source and produced 35\% less yield overall with fish solubles than with feather meal. By contrast, there was relatively little effect of fertilizer source or rate on yield in 'Liberty'. In five of 9 years, yield was $8 \%$ to $20 \%$ greater with weed mat than with sawdust or compost + sawdust. Mulch type had no effect on cumulative yield of 'Duke', but cumulative yield of 'Liberty' was $11 \%$ greater with weed mat than with sawdust or compost + sawdust. Soil temperature was warmer under weed mat than under sawdust, and plants on raised beds covered with weed mat required more irrigation than those grown on flat ground mulched with sawdust. 'Duke' produced heavier, larger, and firmer berries with lower total soluble solids (TSS) than 'Liberty'. However, other treatment effects on berry quality were relatively small and inconsistent. For example, berry weight was greater on raised beds than on flat ground, on average, but only by $3 \%(0.06$ g/berry). Plants on raised beds also produced berries with slightly lower TSS than those on flat ground (15.2\% and $15.7 \%$, respectively, in 'Liberty', and $13.1 \%$ and $13.3 \%$, respectively in 'Duke'). There was no effect of fertilizer source or rate on TSS in 'Liberty' (15.5\% on average), whereas in 'Duke', TSS was highest when fertilized at the high (13.7\%) or low (13.4\%) rate of fish, and was lower when using feather meal (12.9\% and $\mathbf{1 3 . 1 \%}$ for low and high rate, respectively). Plants fertilized with fish produced firmer fruit than with feather meal in five of the 7 years in which the measurements were taken. Also, fertilization with the higher rate of either product increased berry firmness compared with the low rate in six of the 7 years. The impact of mulch was inconsistent through the study period. On average, 'Duke' berries were softest when fertilized with the low $\left(173 \mathrm{~g} \cdot \mathrm{mm}^{-1} \mathrm{deflection}\right)$ and high $\left(176 \mathrm{~g} \cdot \mathrm{mm}^{-1}\right)$ rates of feather meal and were the firmest with the high rate of fish $\left(182 \mathrm{~g} \cdot \mathrm{mm}^{-1}\right)$. In 'Liberty', the low rate of feather meal produced softer fruit $\left(157 \mathrm{~g} \cdot \mathrm{mm}^{-1}\right)$ than the other fertilizer treatments $\left(162 \mathrm{~g} \cdot \mathrm{mm}^{-1}\right.$ on average). When this study was initiated in 2006, the most common organic production system in this region was raised beds with sawdust mulch and fertilizing with a high rate of fish solubles. For this production system, yield for mature plants in our study $(2014-16)$ was the equivalent of $8.9-12.3$ t.ha ${ }^{-1}$ in 'Duke' and 11.8 - 23.7 t.ha ${ }^{-1}$ in 'Liberty'. However, when plants were grown on raised beds with weed mat and fertilized with the high rate of feather meal, yield increased to $10.2-19.3 \mathrm{t} \cdot \mathrm{ha}^{-1}$, depending on year, in 'Duke'. By contrast, there was little effect of production system on yield of mature 'Liberty' plants. These yields, particularly for the best-performing treatment combination in 'Duke', are similar to what are observed in commercial conventional fields or organic farms using similar management practices. Our results showed that choice of organic production system can have significant impact on yield and economic costs and returns.

\footnotetext{
Received for publication 5 June 2017. Accepted for publication 1 July 2017.

The authors value the assistance of Gil Buller and Emily Vollmer, former Faculty Research Assistants at the North Willamette Research and Extension Center, OSU and all of the members of our industry advisory board. We appreciate the funding support provided by the Oregon Blueberry Commission, Washington Blueberry Commission, Northwest Center for Small Fruits Research, and the USDA National Institute of Food and Agriculture (Formula Grant no. OREI 2008-04443).

${ }^{1}$ Corresponding author. E-mail: bernadine.strik@ oregonstate.edu.
}

The Pacific northwestern United States is an important growing region for northern highbush blueberry (Vaccinium corymbosum L.). According to recent U.S. surveys, this region accounted for $20 \%$ of the total conventional area of highbush blueberry (U.S. Department of Agriculture, 2014) and 49\% of the total organic area (U.S. Department of Agriculture, 2010). Organic blueberry production has increased in this region because of strong consumer demand, price premiums of $20 \%$ to $200 \%$ over conventional fruit, and a dry summer climate, which reduces the potential incidence for weeds, insect pests, and leaf and fruit diseases (DeVetter et al., 2015; FernandezSalvador et al., 2017; Strik, 2014). However, there were some challenges specific to organic production that needed to be addressed, including greater production costs and inputs (particularly for fertilization and weed management), limited Organic Materials Review Institute (OMRI)-approved options for disease and insect control, and potential or perceived reduced yields of organic plantings and associated returns (Strik, 2014). In 2006, the production guides available for organic northern 
highbush blueberry in North America were based on anecdotal information (Krewer and Walker, 2006; Kuepper and Diver, 2004). There was little research at that point comparing organic production strategies in blueberry, and most of the production research done in conventional blueberry systems was not applicable to organic systems.

Highbush blueberry is typically planted on raised beds. Raised beds improve soil drainage (Strik, 2007), limit compaction (Magdoff and Van Es, 2010), reduce incidence of root pathogens such as Phytophthora (Bryla and Linderman, 2007), and improve efficiency of machine harvest (Strik and Buller, 2002). However, planting on flat ground can be beneficial to root growth in southern highbush blueberry (complex hybrids based largely on $V$. corymbosum and V. darrowii Camp.) likely due to increased soil moisture and reduced soil temperature during the fruiting season (Spiers, 1995). Furthermore, mechanical weed-control methods are more effective on flat ground than on raised beds (Sciarappa et al., 2008; B. Strik, personal observation).

Weed management is critical for successful production of blueberries (Pritts et al., 1992; Strik et al., 1993), but chemical herbicide options available for organic systems are expensive and limited and usually are not very effective on established perennial weeds (Julian et al., 2012; Larco et al., 2013a). Other forms of weed control such as organic mulches, propane flaming, string trimming, and hand weeding are often used instead (Burkhard et al., 2009; Granatstein and Mullinix, 2008; Krewer et al., 2009; Sciarappa et al., 2008). Organic mulches provide additional benefits in highbush blueberry, including increased yield and plant growth (Clark and Moore, 1991; Goulart et al., 1997; Karp et al., 2006; Kozinski, 2006; Krewer et al., 2009; Savage, 1942; White, 2006). Douglas fir (Pseudotsuga menziesii M.) sawdust is commonly used to mulch blueberry plantings in Oregon, Washington, and British Columbia, but sawdust has become expensive in the region (Julian et al., 2011a), and it tends to immobilize a considerable amount of the $\mathrm{N}$ applied from fertilizers (White, 2006). Some growers are using compost in addition to sawdust to provide additional nutrients and organic matter (Gale et al., 2006; Larco et al., 2014). Municipal yard debris compost is readily available in many production regions and may be suitable for commercial blueberry production (Sullivan et al., 2014).

Weed mat (perforated landscape fabric) is approved for use as a weed barrier by the United States Department of Agriculture (USDA) Organic National Program (USDA-AMS-NOP, 2011), and because of economic advantages, it has been adopted by both organic and conventional blueberry growers (Julian et al., 2012; Strik and Vance, 2017). However, increased soil temperature under the weed mat can reduce plant growth (Neilsen et al., 2003; Williamson et al., 2006) and yield (Krewer et al., 2009). Larco et al. (2013a) reported that northern highbush blueberry grew less with weed mat than with sawdust mulch by the end of the first two growing seasons; however, the plants had greater yield with weed mat in the second year, which was the first season of fruit production.

In addition to weed management, availability and affordability of fertilizers are of critical importance for the economical production of organic blueberry (Strik, 2014). Fish solubles and feather meal are common fertilizers used by organic blueberry growers. Fish solubles are typically applied by fertigation through the drip irrigation system, especially when weed mat is used and other application methods are less practical or more expensive. Feather meal is a granular product applied to the soil surface. Both fertilizers mineralize readily on application and quickly release $\mathrm{N}$ and other nutrients (Bary et al., 2016; Hartz and Johnstone, 2006). Northern highbush blueberry requires fertilizer applications of $25-100 \mathrm{~kg} \cdot \mathrm{ha}^{-1} \mathrm{~N}$ per year to maximize growth and production in conventional plantings (Bañados et al., 2012; Chandler and Mason, 1942; Eck, 1988; Griggs and Rollins, 1947; Hanson, 2006; Hart et al., 2006), but little information is available on the fertilizer requirements in organic systems.

The objectives of this research trial were to evaluate the impact of planting method, cultivar, mulch, and fertilizer source and rate on plant growth, yield, and fruit quality from establishment through maturity. Yield for the first fruiting season (2008) as well as treatment impacts on growth are reported elsewhere (Larco et al., 2013a, 2013b, 2014). Impacts of treatments from 2008 to 2016 are included here. We reported on the economic impacts of mulch and weed-control options during establishment in Julian et al. (2012) and throughout the study in Strik and Vance (2017).

\section{Materials and Methods}

The 0.4-ha trial was established in Oct. 2006 at Oregon State University's North Willamette Research and Extension Cen-

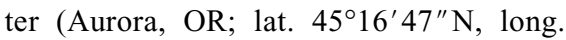
$\left.122^{\circ} 45^{\prime} 23^{\prime \prime} \mathrm{W}\right)$. The planting was certified organic in the first cropping year (2008) by a USDA-accredited agency (Oregon Tilth, Certified Organic, Corvallis, OR). The soil, which is mapped as a Willamette silt loam (a fine-silty, mixed, superactive mesic Pachic Ultic Argixeroll), contained 3.7\% organic matter content at planting. This study was conducted from 2008 through 2016. Further details on planting establishment are provided elsewhere (Larco et al., 2013a, 2013b).

Treatments. There were 48 treatment combinations arranged in a balanced factorial $(2 \times 4 \times 2 \times 3)$ split-split-plot design with five replicates. The main plots were planting method [raised beds $(\approx 0.3-\mathrm{m}$ high) or flat ground], the subplots were fertilizer rate and source ( 2 rates $\times 2$ sources), and the sub-subplots were mulch treatment ("compost + sawdust," sawdust, or weed mat) and cultivar (earlyseason 'Duke' and midseason 'Liberty'). Subsubplots were 4.6-m long with six plants in each sub-subplot at establishment. One plant was removed from each plot for biomass measurements in Oct. 2007 and 2008 (Larco et al., 2013a, 2013b). The plants removed in 2007 were replaced with new plants, but those removed in 2008 were not replaced because it was considered too late for good establishment among the older plants. Plant spacing was $0.8 \mathrm{~m}$ by $3.0 \mathrm{~m}$ (4385 plants/ha).

Mulch treatments were a) a 9-cm-deep layer of douglas fir sawdust $\left(360 \mathrm{~m}^{3} \cdot \mathrm{ha}^{-1}\right)$; b) a 4-cm-deep layer of municipal yard debris compost $\left(152 \mathrm{~m}^{3} \cdot \mathrm{ha}^{-1}\right)$ covered by 5 -cm-deep douglas fir sawdust $\left(200 \mathrm{~m}^{3} \cdot \mathrm{ha}^{-1}\right)$ (compost + sawdust); and c) weed mat [black, woven polyethylene groundcover (water flow rate of $6.8 \mathrm{~L} \cdot \mathrm{m}^{-2} \cdot \mathrm{h}^{-1} ; 0.11$ $\mathrm{kg} \cdot \mathrm{m}^{-2}$; TenCate Protective Fabrics; OBC Northwest Inc., Canby, OR)]. Holes (20-cm diameter) cut in the weed mat for the plants were mulched with 5 -cm-deep douglas fir sawdust $\left(1.4 \mathrm{~m}^{3} \cdot \mathrm{ha}^{-1}\right)$. The intent of the compost + sawdust treatment was to have the sawdust mulch act as a barrier to weed seed germination in the more nutrient-rich compost layer. The organic mulches were initially applied in 2006, just after planting, and were replenished in Jan. 2011 and 2013 and Feb. 2015; in 2015, additional mulch was only needed on raised beds. The weed mat (1.5-m wide) was centered over the row and installed just before planting. It was replaced with "zippered" weed mat (two overlapping pieces placed on each side of the row and secured in the middle using landscape staples) in the winter of 2010-11. This allowed us to "open" the weed mat and apply granular fertilizers, as needed. The mulches are further characterized for their properties in Sullivan et al. (2015).

A permanent grass cover crop (certified organic Festulolium braunii K. Richt.) was grown in the row aisles and mowed during the growing season, as required. Depending on the year, weeds in the plots mulched with compost + sawdust were controlled by various methods, including using OMRIapproved postemergent acetic acid (20\%) WeedPharm ${ }^{\circledR}$, Pharm Solutions, Inc., Port Townsend, WA), lemon grass oil or d-limonene (GreenMatch $\mathrm{EX}^{\circledR}$ and Avenger ${ }^{\circledR}$, respectively, Cutting Edge Formulations, Inc., Buford, GA), propane flaming, and handweeding. Propane flaming was only used in 2007, as it was found ineffective, and there were concerns of fire danger and plant damage, as noted by others (Granatstein and Mullinix, 2008). The sawdust plots and the planting-hole area of the weed-mat plots were hand-weeded only, as needed during the season. Labor and product costs are reported elsewhere (Julian et al., 2012; Strik and Vance, 2017).

Fertilizer source and rate treatments were granular feather meal $(11 \%$ to $13 \% \mathrm{~N}$, depending on product or batch) or fish solubles (pH-stabilized; $4 \%$ to $5 \% \mathrm{~N}$ ). Both were applied at either a "low" or "high" rate of 29 and $57 \mathrm{~kg} \cdot \mathrm{ha}^{-1} \mathrm{~N}$, respectively, in 2007-09 
and then increased incrementally as the planting matured to 73 and $140 \mathrm{~kg} \cdot \mathrm{ha}^{-1} \mathrm{~N}$, respectively, by 2013. Feather meal was applied in two equal split applications in March and May. In weed-mat plots, the feather meal was concentrated in the openings in 2007-10, and later, once the zippered weed mat was installed, it was broadcast on the entire plot. Fish fertilizer was diluted with 10 parts water (v/v) and applied by hand as a drench around the base of the plants in 2007-09, side dressed with a sprayer on each side of the row in 2010, and injected through the drip system (fertigation) in 2011-16. Fertilization with fish was split into seven equal applications every 2 weeks from midApril to early July.

The cultivars were chosen because of their popularity at the time and their different fruiting seasons. Fertility management was also expected to be more difficult in 'Duke' (more sensitive to $\mathrm{N}$ rate and soil $\mathrm{pH}$ ) than in 'Liberty', based on our experience in conventional systems.

Data collection. Plants were irrigated using a single line of polyethylene drip tubing (Netafim, Fresno, CA) containing $2-\mathrm{L} \cdot \mathrm{h}^{-1}$ pressure-compensating, inline emitters every $0.3 \mathrm{~m}$. Lines were located along the row near the base of plants and covered with the mulch or weed mat. A second line of drip (located on the other side of the plant crown) was also installed right after planting in weed-mat plots in anticipation of possible requirements for additional irrigation associated with higher temperatures in the treatment (Cox, 2009; Neilsen et al., 2003; Williamson et al., 2006). Irrigation was controlled by electric solenoid valves and an automatic timer set weekly and scheduled based on changes in soil water content. Rows planted on raised beds or flat ground (main plot effect) and with organic mulch (sawdust and compost + sawdust) or weed mat could be irrigated independently. The total amount of irrigation water applied to these treatments was recorded using water meters. Irrigation was adjusted in the treatments to maintain soil water content at $25 \%$ to $30 \%$ during the growing season. Soil water content was measured between two plants in each plot to a depth of $30 \mathrm{~cm}$ using a time domain reflectometry system and waveguides (model Trase System 1; SoilMoisture Equip. Corp., Santa Barbara, CA). Leaf water potential was also measured periodically in the plots using a pressure chamber (model 600; PMS Instrument Co., Corvallis, OR) (Larco, 2010) to ensure the plants were well watered (Bryla and Strik, 2007). Irrigation was generally applied from mid to late May through September each year.

Soil temperature data were collected using HOBOS $8 \mathrm{~K}$ (Onset Corporation, Bourne, MA) from 2007 to 2009 and using copper-constantan wire thermocouples and a CR1000 data logger (Campbell Scientific Instruments, Logan, UT) from 2010 to 2014. All readings were taken from June through December each year. The sensors and thermocouples were installed in two random plots each of the flat ground and raised bed treatments mulched with sawdust and weed mat (high rate of fish solubles only). In each case, temperature was measured $0.1 \mathrm{~m}$ from the plant crown at a depth of $5 \mathrm{~cm}$ below the soil-mulch interface. Monthly mean, maximum, and minimum soil temperatures collected during the first 2 years after planting were presented by Larco (2010). Here, we present diurnal changes in temperature that were measured every 15 min during a midsummer period in July 2014, when the planting had reached maturity.

Plant tissue (most-recent fully expanded leaves in late July to early August from three replicates) and soil (autumn, 'Duke' plots only; five reps) samples were collected each year. Soil samples were collected between plants to a depth of $0.2 \mathrm{~m}$ at the center of the row using a 2.4-cm diameter chrome-plated steel soil probe (Soil Sampler Model Hoffer; JBK Manufacturing, Dayton, OH). Mulch was removed from the soil surface before taking the samples and replaced afterward. Soil and tissue samples were analyzed for macro- and micronutrients, organic matter, and $\mathrm{pH}$ by a commercial testing laboratory (Brookside Laboratories, New Bremen, $\mathrm{OH})$. Leaf tissue analyses indicated that the concentration of B was low in the leaves $(<30 \mathrm{ppm})$ in 2009 and 2012-15 (Hart et al., 2006). Therefore, borate was applied to the soil in Autumn 2010 and Spring 2013 and 2014, and boric acid was applied to the foliage in Spring 2010, 2015, and 2016, at rates of $0.7-2.2 \mathrm{~kg} \cdot \mathrm{ha}^{-1} \mathrm{~B}$ per year. The concentration of $\mathrm{Ca}$ and $\mathrm{Mg}$ were also low in the leaves in 2012. Therefore, gypsum and epsom salt were applied at rates of $245 \mathrm{~kg} \cdot \mathrm{ha}^{-1} \mathrm{Ca}$ and $56 \mathrm{~kg} \cdot \mathrm{ha}^{-1} \mathrm{Mg}$, respectively, before the 2013 growing season.

Ripe fruit were harvested by hand about every $7 \mathrm{~d}$ from each experimental unit (plot). 'Duke' was harvested two to three times per year, somewhere between 13 June and 27 July each year, and 'Liberty' was harvested three to four times per year, somewhere between 6 July and 24 Aug. The fruit were weighed from each plot to calculate yield and sold to a commercial organic berry packer (fresh and processed markets) to estimate the returns in each treatment (Strik and Vance, 2017). During the course of the study, any presence of the commonly occurring pollenborne Blueberry shock virus (B1ShV) was noted, and the proportion of the plot showing symptoms (necrotic flowers), and thus not producing fruit, was estimated annually. We did not see a high incidence of B1ShV in the planting but adjusted yield to account for any fruit loss from the virus. There was no evidence that infection by B1ShV was treatment related.

A random subsample of 25 berries was also taken from the plots on each harvest date to determine average berry weight (a weighted seasonal average mass was then calculated) and berry firmness and diameter. Berry firmness and diameter were measured using a firmness tester (FirmTech II;
BioWorks, Inc., Wamego, KS). The subsamples were then macerated by hand in a zippered plastic bag and measured for percent TSS using a temperature-compensated digital refractometer (Atago, Bellevue, WA). Berry diameter, firmness, and TSS are reported as seasonal averages. There were insufficient resources to take these measurements in 2015 and 2016.

Planting management. Other than the aforementioned treatments, all plots were managed similarly. Scouting or trapping to monitor any incidence of virus, disease, or insect pests was done annually, per standard practice (DeFrancesco et al., 2016). To help control spotted wing drosophila [Drosophila suzukii (Matsumura)], the planting was sprayed with either a spinosad (metabolites of Saccharopolyspora spinosa) insecticide (Entrust $^{\circledR}$ SC; Dow Agro Science, Indianapolis, IN) or a pyrethrin (PyGanic EC 1.4; Valent, Walnut Creek, CA) in 2011-16. The products were applied once every 7-14 d from the time when 'Liberty' fruit first turned blue through the end of harvest. 'Duke' was only sprayed in 2015 and 2016 (one time per year) because of an earlier presence of the pest, as determined by monitoring traps in the field. Bacillus subtilis fungicide (Serenade ${ }^{\circledR}$ MAX; AgraQuest, Davis, CA) was applied to the field at the recommended label rate in spring 2013-16 to control gray mold (Botrytis cinerea Pers.). A scare alarm (Bird Gard LLC, Sisters, OR) and laser (AgriLaser; Bird Control Group, Delft, the Netherlands; 2016 only) were used to reduce depredation from birds. No other pests were observed or identified in the planting through the course of the study.

Plants were pruned each winter to maintain a balance of vegetative growth and fruit production (Strik and Buller, 2005; Strik et al., 1990, 1993).

Statistical analysis. Data were analyzed using PROC MIXED in SAS software package ver. 9.3 (SAS Institute, Cary, NC). Yield and fruit quality traits were first characterized across years using a split-split-split plot design [year as the main effect $(n=7-9)$, planting method as the subplot $(n=2)$, fertilizer rate and source as the sub-subplot $(n=4)$, and combinations of cultivar and mulch as sub-sub-subplots $(n=6)]$ and then reanalyzed within years using a complete factorial of the original split-split-plot design. Contrasts were used to compare the effect of fertilizer source and rate and mulch type on measured variables. Means were separated at the $5 \%$ level using Tukey's honest significant difference test.

\section{Results and Discussion}

The impacts of planting method, fertilizer, mulch, and cultivar on fruit quality traits and yield over this 10-year study were complex with many interactions among treatments (Table 1).

Yield. Yield increased as the plants matured (Figs. 1-3) and reached a maximum or "mature" level by the eighth growing season 
Table 1. Results of analysis of variance for the impact of year (2008-16; $n=9$ for yield; $n=7$ for fruit quality variables), planting method (raised bed or flat ground; $n=2$ ), fertilizer source and rate (feather meal or fish solubles at low or high rate of nitrogen; $n=4$ ), mulch (sawdust, yard debris compost topped with sawdust, weed mat; $n=3$ ) and cultivar (Duke, Liberty; $n=2$ ). Actual $P$ value provided unless nonsignificant.

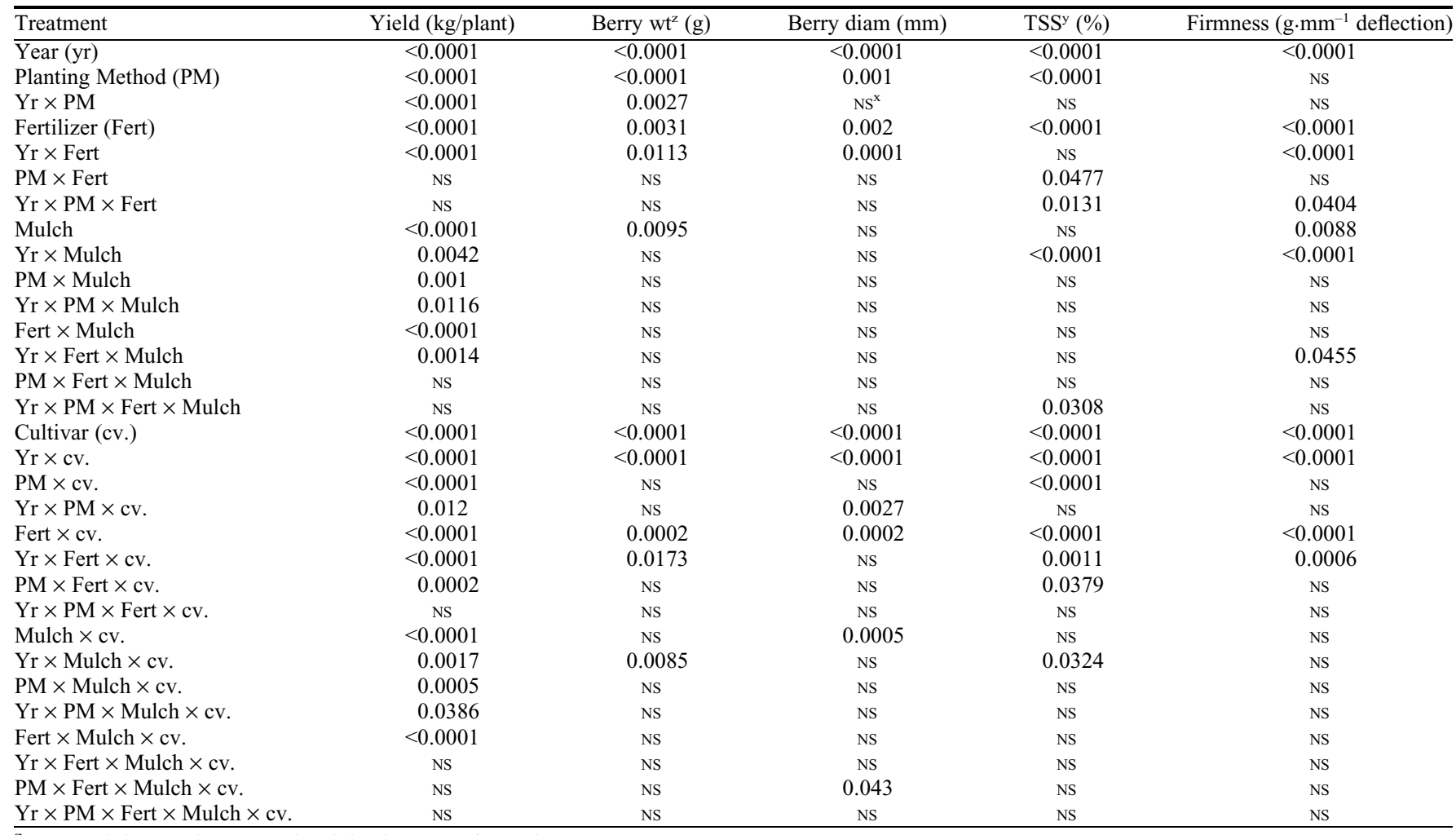

${ }^{\mathrm{z}}$ Berry weight was the seasonal weighted average for each year (2008-14).

${ }^{\mathrm{y}} \mathrm{TSS}=$ average total soluble solids for the year (2008-14).

$\mathrm{x}_{\mathrm{NS}}=$ nonsignificant at $P>0.05$.
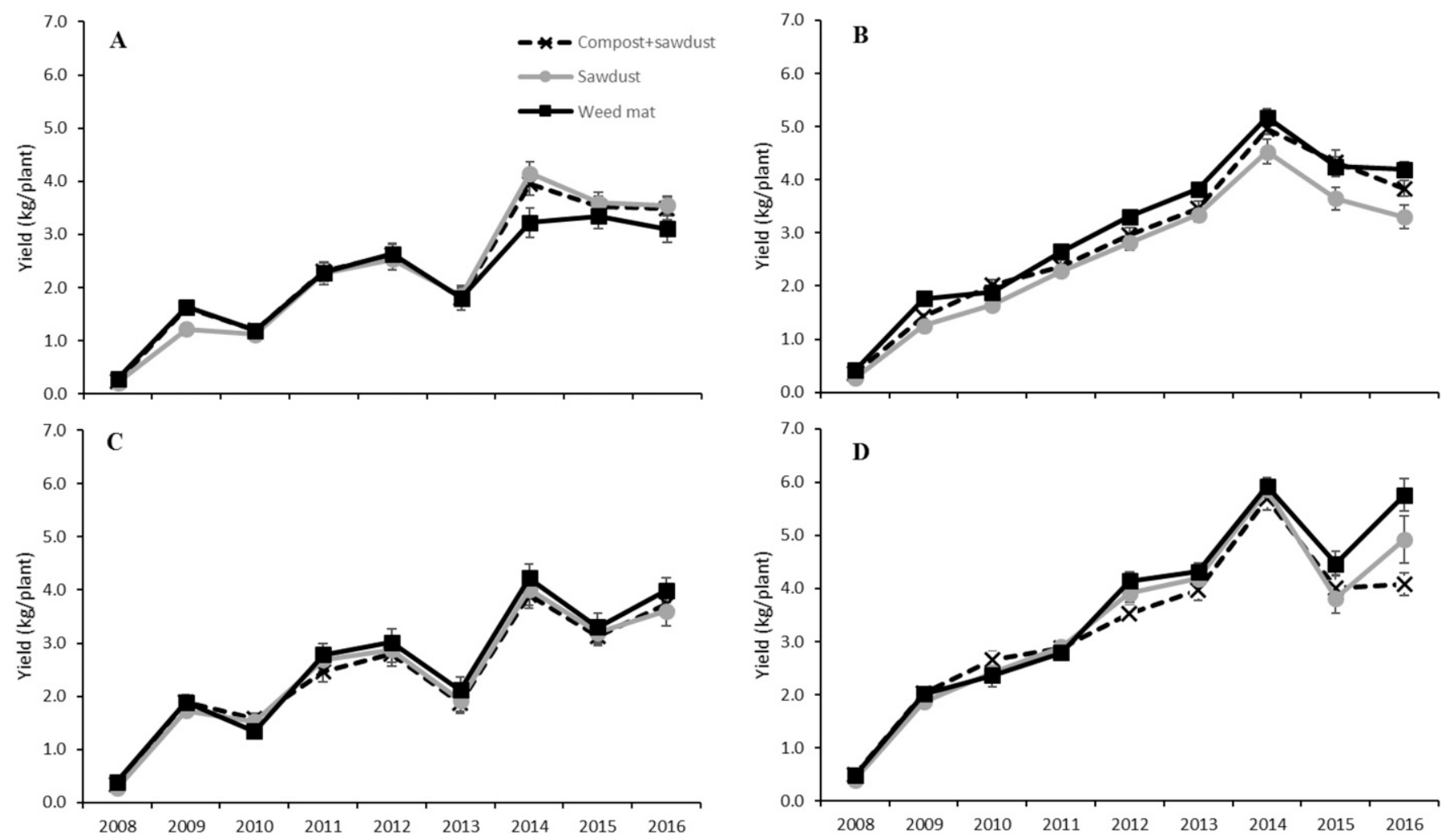

Fig. 1. Effect of using organic mulch (compost + sawdust or sawdust only) or weed mat on yield of (A, C) 'Duke' and (B, D) 'Liberty' northern highbush blueberry. The plants were grown on $(\mathbf{A}, \mathbf{B})$ flat ground or $(\mathbf{C}, \mathbf{D})$ raised beds in a certified organic planting in western Oregon and harvested from the second through the 10th growing season (2008-16). Means are averaged over four fertilizer treatments [feather meal and fish solubles applied at low (29-73 kg.ha ${ }^{-1} \mathrm{~N}$ per year) or high (57-140 kg.ha ${ }^{-1} \mathrm{~N}$ per year) rates]. Error bars represent $\pm 1 \mathrm{SE}$. 

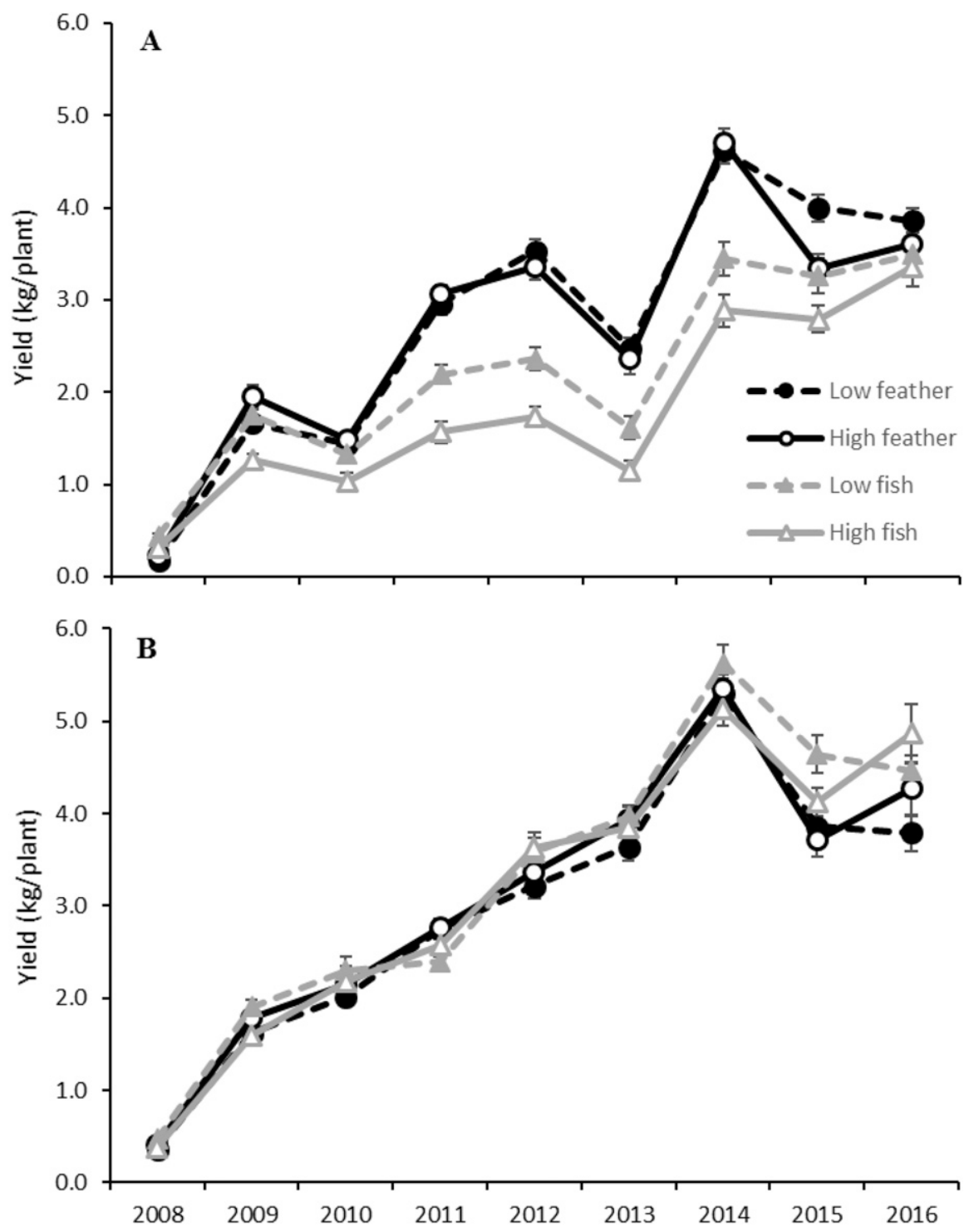

Fig. 2. Effect of fertilizing with low (29-73 kg.ha-1 N per year) or high (57-140 kg.ha-1 $\mathrm{N}$ per year) rates of feather meal or fish solubles on yield of (A) 'Duke' and (B) 'Liberty' northern highbush blueberry. The plants were grown in a certified organic planting in western Oregon and harvested from the second through the 10th growing season (2008-16). Means are averaged over a combination of two planting method (flat ground and raised beds) and three mulch (compost + sawdust, sawdust, and weed mat) treatments. Error bars represent \pm 1 SE.

(2014), which is typical for western Oregon (Julian et al., 2011a, 2011b). Yield was unusually low in 'Duke' in 2013 because of a high level of bird depredation (B. Strik, personal observation). Yield significantly declined in both cultivars from 2014 to 2015 ( $P \leq$ 0.05 ) but was similar in 2015 and 2016. Based on our experience, once plants reach full maturity, yield tends to fluctuate from year to year as a result of differences in pruning and weather conditions. Similar fluctuations in yield were noted in another long-term organic study on 10 cultivars of northern highbush blueberry (Strik et al., 2017).

There was an interaction between planting method, mulch type, and cultivar on yield over the study period (Table 1; Fig. 1A-D). Planting on raised beds had more of a positive effect on yield compared with flat ground during the establishment years than when at the end of the first fruiting season (2008). However, we did find more root production in raised beds than on flat ground for 'Duke' during the establishment years (ValenzuelaEstrada et al., 2011). Although the soil type at this location would be considered ideal for blueberry production in our region, it is possible that improved plant growth and yield on raised beds were due to better aeration and root growth during the study period.

There was a significant interaction of fertilizer (source and rate) and cultivar on yield over the study period (Table 1). In 'Duke', plants fertilized with feather meal had a greater yield in most years of the study compared with those fertilized with fish, with yield being particularly low at the high rate of fish (Fig. 2A). By contrast, there was relatively little effect of fertilizer source or rate in 'Liberty' (Fig. 2B). When treatment effects were analyzed by year, plants fertilized with feather meal had a greater average yield than those fertilized with fish (significant contrast for fertilizer source) in six of the nine study years (Table 2). There was no significant effect of fertilizer rate in any year except for 2015, when plants fertilized with the low rate of $\mathrm{N}$ had a greater yield than those receiving the high rate, on average.

Cumulative yield was significantly affected by fertilizer, fertilizer $\times$ mulch, fertilizer $\times$ cultivar, and mulch $\times$ cultivar (Table 3 ). Plants fertilized with feather meal averaged $10 \%$ greater yield than those fertilized with fish. In addition, plants receiving the low rate of fertilizer had a $4 \%$ greater cumulative yield than those at the high rate. 'Duke' plants fertilized with feather meal had a greater cumulative yield $(24.3 \mathrm{~kg} / \mathrm{plant})$ than those fertilized with the low $(20.0 \mathrm{~kg} / \mathrm{plant})$ or high rate $(16.1 \mathrm{~kg} /$ plant $)$ of fish (data not shown). By contrast, the cumulative yield of 'Liberty' was similar when fertilizing with the low or high rate of fish and the high rate of feather meal (averaging $28.4 \mathrm{~kg} /$ plant), and only plants fertilized with the low rate of feather meal had significantly reduced yield $(26.5 \mathrm{~kg} / \mathrm{plant})$ compared with the low rate of fish $(29.2 \mathrm{~kg} / \mathrm{plant})$ (data not shown). It is clear that 'Duke' was particularly sensitive to fertilizer source, with fish leading to a $35 \%$ reduction in cumulative yield compared with feather meal.

When plants were mature, the relative fertilizer product costs were $\$ 2,128$ /ha and $\$ 4,235 /$ ha for the high rate of feather meal $(\$ 15.20 / \mathrm{kg}$ of $\mathrm{N})$ and fish $(\$ 30.25 / \mathrm{kg}$ of $\mathrm{N})$, respectively. Although fertilizing with the low rate of feather meal would thus reduce product costs considerably compared with the high rate of fish $(\approx \$ 3,171 /$ ha less $)$, there is risk that there would be insufficient $\mathrm{N}$ available at critical times with an associated reduction in yield, as we noted in 'Liberty'. Application of feather meal also requires opening and closing the weed mat twice per year (or once if left open in between applications) compared with fertigation with fish solubles. Although the weed mat may need to be opened for other reasons (e.g., checking 

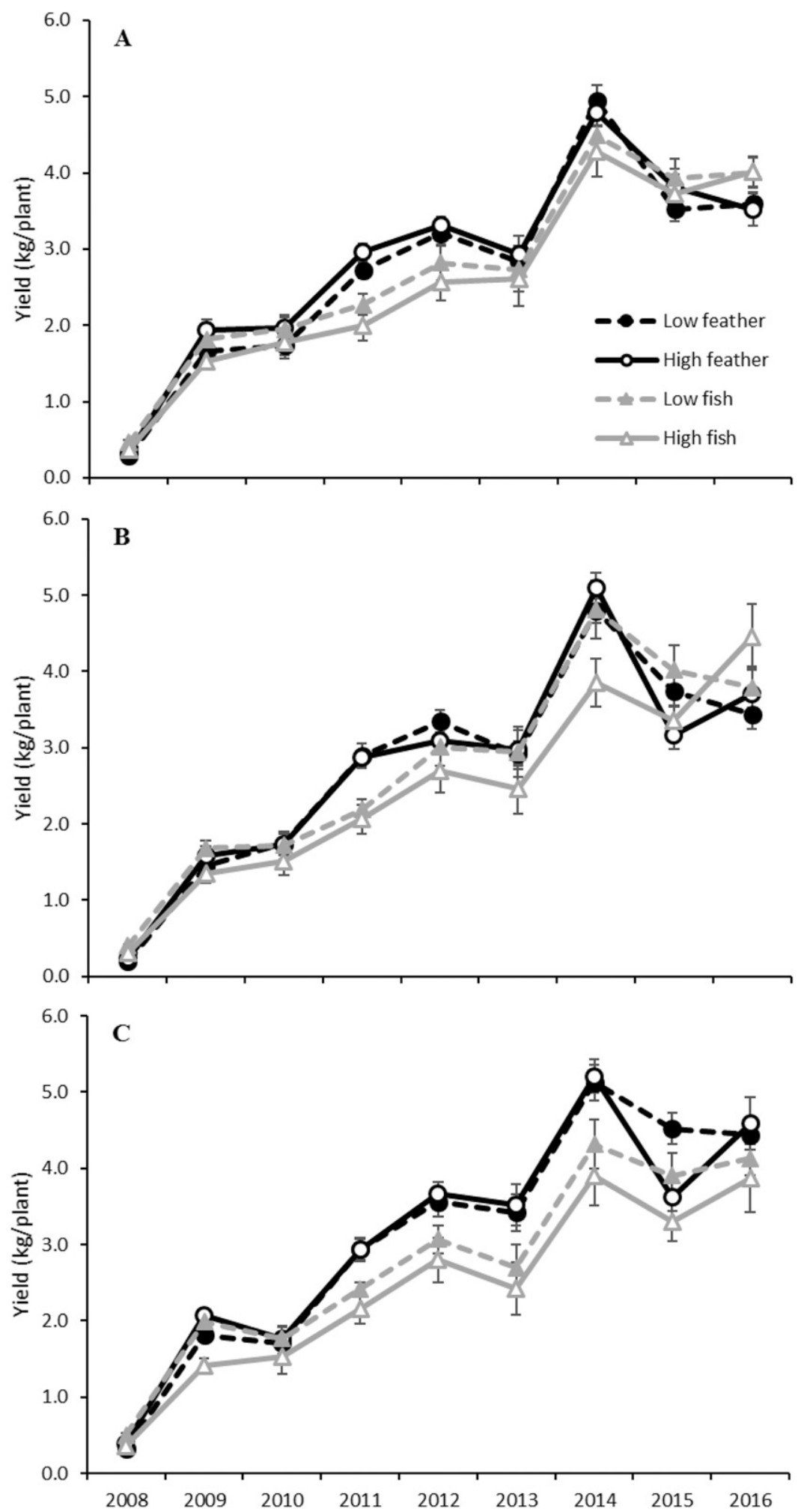

Fig. 3. Effect of fertilizing with low (29-73 kg.ha ${ }^{-1} \mathrm{~N}$ per year) or high $\left(57-140 \mathrm{~kg} \cdot \mathrm{ha}^{-1} \mathrm{~N}\right.$ per year) rates of feather meal or fish solubles on yield of northern highbush blueberry. The plants were mulched with (A) compost + sawdust, (B) sawdust, or (C) weed mat in a certified organic planting in western Oregon and harvested from the second through the 10th growing season (2008-16). Means are averaged over a combination of two planting method (flat ground and raised beds) and two cultivar ('Duke' and 'Liberty') treatments. Error bars represent \pm 1 SE.

the irrigation system and adding organic matter or other granular fertilizers), this would add an estimated $\$ 2,625 /$ ha in labor costs (at $\$ 15 / h$ ) per year (Julian et al., 2011b).
Growers who prefer fertigation could use fish solubles at a lower rate (reducing product costs by $\$ 1,585 /$ ha in our study), as we found that yield of plants was equivalent or higher at the low rate of fish compared with the high rate. Of note is that these fertilizer products are considerably more expensive than what might commonly be used for conventional production - $\$ 169 / \mathrm{ha}$ for granular urea and \$206/ha for liquid urea (fertigation), if applied at an equivalent high rate of $\mathrm{N}$ per hectare. Fertilization in organic production systems thus adds a considerable management cost as compared with conventional.

Plants grown with weed mat had a greater yield than those grown with sawdust or compost + sawdust (contrast) in five of the 9 years (Table 2). During the first 3 years of establishment, plants mulched with compost + sawdust had a greater yield than when sawdust was used (contrast, Table 2), but there was no difference between these two mulches in the later years of the study. Our results of improved growth in young, establishing blueberry when using compost as a mulch agree with the findings of Burkhard et al. (2009); however, their study did not go long enough to test long-term impacts. Choi et al. (2011) reported no effect of a wood chip mulch compared with weed mat in organic apple trees (Malus $\times$ pumila Mill.) in a 6-year study, although cultivars did respond differently. In a 5-year study, the yield of rabbiteye blueberry plants was greater with pine straw or pine bark mulch than with weed mat (Krewer et al., 2009).

When plants were grown with weed mat mulch, fertilization with fish at either rate led to particularly low yield in 2011-14 compared with compost + sawdust or sawdust mulch alone (Fig. 3). This is a rather important finding as weed mat is the most commonly used mulch in organic plantings established since 2006 in this region. There was less of an effect of fertilizer source with sawdust mulch (a reduction in yield occurred mainly for the high rate of fish). In compost + sawdust mulch, fertilization with fish reduced yield relative to feather meal in 2011 and 2012.

Cumulative yield was greatest for plants grown with weed mat and fertilized with feather meal, whereas when plants were fertilized with fish yield was reduced with no effect of mulch type (Fig. 4). There was no effect of mulch type on cumulative yield of 'Duke' (21.2 kg/plant, on average), but in 'Liberty', cumulative yield was greater with weed mat ( $29.8 \mathrm{~kg} /$ plant) than with sawdust or compost + sawdust $(26.9 \mathrm{~kg} /$ plant $)$ (data not shown).

Berry weight and size. Berry weight was affected by all treatments (main effect), as well as many significant interactions (Table 1). Berry weight was greater on raised beds than on flat ground when plants were young (2008-09) or mature (2013-14), but not during the other establishment years (data not shown). Although average berry weight for the entire study period was significantly greater on raised beds than on flat ground (Table 3), it is unlikely the difference found ( $3 \%$ or $0.06 \mathrm{~g}$ ) would be significant to the industry or markets. In 'Duke', berry weight was significantly lower for plants fertilized 
Table 2. Impact of planting method, fertilizer source and rate, mulch type, and cultivar on the average yield per plant of northern highbush blueberry from the second growing season or first fruiting year (2008) through 2016 when grown in a certified organic planting in western Oregon.

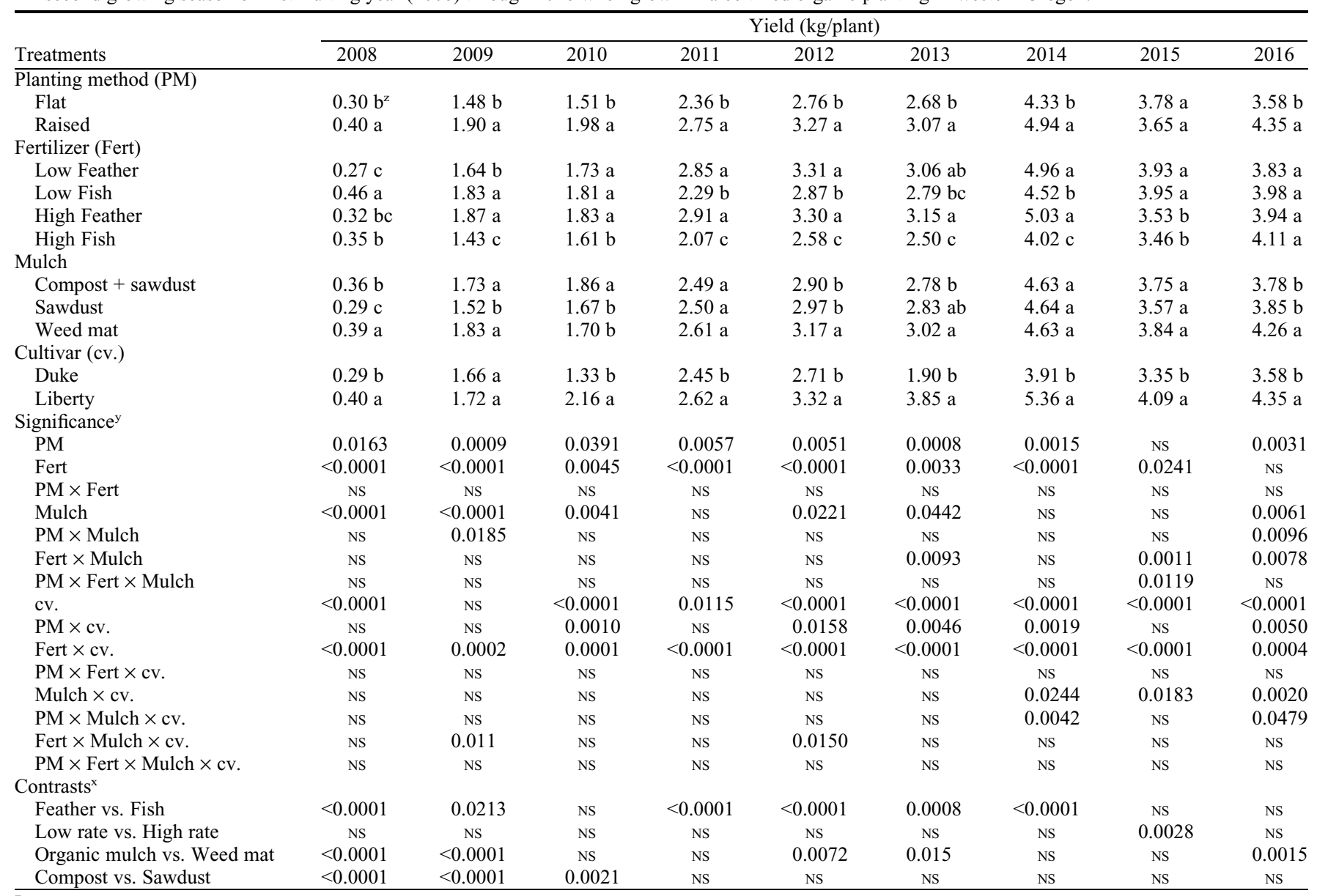

${ }^{\mathrm{z}}$ Means followed by the same letter are not significantly different as determined by analysis of variance using Tukey honest significant difference test $(P>0.05)$.

${ }^{\mathrm{y}}$ Actual $P$ values provided unless nonsignificant (Ns; $P>0.05$ ).

${ }^{x}$ Contrasts for fertilizer source ("Feather vs. Fish," averaged over nitrogen rate); N rate ("Low rate vs. High rate," averaged over source); the average response of sawdust and compost + sawdust mulch compared with weed mat ("Organic mulch vs. Weed mat"); and compost + sawdust mulch compared with sawdust mulch alone ("Compost vs. Sawdust").

with the high rate of fish during several of the establishment years, whereas 'Liberty' plants fertilized with fish had a greater berry weight in several years (Table 1; Fig. 5). There was a significant year $\times$ mulch $\times$ cultivar interaction for berry weight (Table 1). Berry weight was lower with weed mat in 'Duke' in 2010-11 than the other mulches, whereas in 'Liberty', weed mat and compost + sawdust had similar berry weight in all years, whereas sawdust had the greatest berry weight in 2013 (data not shown).

'Duke', on average, produced significantly larger berries than 'Liberty' over the course of the study (Table 3). Although there was a significant fertilizer $\times$ cultivar $\times$ mulch interaction, the response of berry diameter to treatments was similar to that described previously for berry weight (data not shown). In addition, treatments differed $<1 \mathrm{~mm}$ in berry diameter and thus were likely not of economic significance.

Berry TSS and firmness. Berry TSS was affected by year, fertilizer, and cultivar (main effects), and by several interactions (Table 1). In 'Liberty', plants fertilized with the low rate of feather meal had lower TSS than the other fertilizer treatments in 2011, but there was little treatment effect in other years (data not shown). In 'Duke', plants fertilized with the high rate of fish had a greater TSS than other treatments from 2008 to 2012 (data not shown). Over the study period, on average, plants fertilized with the low rate of $\mathrm{N}$ had a lower berry TSS than those receiving the high rate, and those fertilized with fish had a higher berry TSS than when feather meal was used (Table 3). However, the cultivars differed, as there was no effect of fertilizer source or rate on TSS in 'Liberty' $(15.5 \%$ on average), whereas in 'Duke', TSS was highest when fertilized at the high $(13.7 \%)$ or low $(13.4 \%)$ rate of fish and was significantly lower when using feather meal $(12.9 \%$ and $13.1 \%$ for low and high rate, respectively; data not shown).

While there was a year $\times$ mulch $\times$ cultivar interaction on TSS (Table 1), the differences were inconsistent and relatively small (data not shown), and there was no effect of mulch on TSS over the study period, on average (Table 3$)$. There was a year $\times$ planting method $\times$ mulch $\times$ fertilizer interaction on TSS (Table 1). For plants grown on flat ground, TSS was higher when fertilized with the high rate of fish and when grown with compost + sawdust and weed mat; with sawdust mulch, the high rate of fish was similar to the other fertilizers except for a lower TSS when the low rate of feather meal was used (data not shown). Burkhard et al. (2009) found increased TSS in blueberry mulched with seafood waste compost as compared with other mulches in Nova Scotia, Canada, whereas Tertuliano et al. (2012) found little effect of mulch type on berry weight and TSS in rabbiteye blueberry in Georgia. In addition, there was no effect of various organic fertilizers on TSS in southern highbush blueberry at harvest in Chile (Echeverría et al., 2009).

When plants were grown on raised beds, fertilization with the high rate of fish increased TSS only in plants grown with sawdust or weed mat mulch (data not shown). Over the course of the study (Table 3), plants grown on raised beds produced berries with a lower TSS than those on flat ground, particularly in 'Liberty' ( $15.2 \%$ vs. $15.7 \%$, respectively) as compared with 'Duke' (13.1\% vs. $13.3 \%$, respectively) (data not shown). 
Table 3. Impact of planting method, fertilizer source and rate, mulch type, and cultivar on the cumulative yield per plant of northern highbush blueberry from the second (first fruiting year) through the 10th growing season (2008-16) and average fruit quality (2008-14) when grown in a certified organic planting in western Oregon.

\begin{tabular}{|c|c|c|c|c|c|}
\hline & Cumulative yield (kg/plant) & Berry $w^{z}(g)$ & Berry diam $(\mathrm{mm})$ & $\operatorname{TSS}^{\mathrm{y}}(\%)$ & Firmness $\left(\mathrm{g} \cdot \mathrm{mm}^{-1}\right.$ deflection) \\
\hline Raised & $26.7 \mathrm{a}$ & $2.24 \mathrm{a}$ & $17.9 \mathrm{a}$ & $14.2 \mathrm{~b}$ & $170 \mathrm{a}$ \\
\hline \multicolumn{6}{|l|}{ Fertilizer (Fert) } \\
\hline Low Fish & $24.6 \mathrm{a}$ & $2.25 \mathrm{a}$ & $17.9 \mathrm{a}$ & $14.4 \mathrm{~b}$ & $169 \mathrm{~b}$ \\
\hline High Feather & $25.8 \mathrm{a}$ & $2.21 \mathrm{~b}$ & $17.8 \mathrm{ab}$ & $14.3 \mathrm{~b}$ & $169 \mathrm{~b}$ \\
\hline High Fish & $22.2 \mathrm{~b}$ & $2.20 \mathrm{~b}$ & $17.8 \mathrm{~b}$ & $14.6 \mathrm{a}$ & $173 \mathrm{a}$ \\
\hline Weed mat & $25.4 \mathrm{a}$ & $2.19 \mathrm{~b}$ & $17.8 \mathrm{a}$ & $14.3 \mathrm{a}$ & $169 \mathrm{a}$ \\
\hline \multicolumn{6}{|l|}{ Cultivar (cv.) } \\
\hline Duke & $21.2 \mathrm{~b}$ & $2.29 \mathrm{a}$ & $18.4 \mathrm{~b}$ & $13.2 \mathrm{~b}$ & $177 \mathrm{a}$ \\
\hline Liberty & $27.9 \mathrm{a}$ & $2.14 \mathrm{~b}$ & $17.3 \mathrm{a}$ & $15.5 \mathrm{a}$ & $161 \mathrm{~b}$ \\
\hline \multicolumn{6}{|l|}{ Significance ${ }^{\mathrm{w}}$} \\
\hline PM & 0.0377 & 0.0008 & NS & 0.0002 & NS \\
\hline PM $\times$ Fert $\times$ Mulch & NS & NS & NS & NS & NS \\
\hline cv. & $<0.0001$ & $<0.0001$ & $<0.0001$ & $<0.0001$ & $<0.0001$ \\
\hline $\mathrm{PM} \times \mathrm{cv}$ & 0.0004 & NS & NS & 0.0021 & NS \\
\hline Fert $\times$ cv. & $<0.0001$ & 0.0017 & 0.009 & $<0.0001$ & 0.0021 \\
\hline $\mathrm{PM} \times$ Fert $\times \mathrm{cv}$ & NS & NS & NS & NS & NS \\
\hline Mulch $\times$ cv & 0.0107 & NS & 0.0192 & NS & NS \\
\hline $\mathrm{PM} \times$ Mulch $\times \mathrm{cv}$ & NS & NS & NS & NS & NS \\
\hline Fert $\times$ Mulch $\times$ cv & NS & NS & NS & NS & NS \\
\hline $\mathrm{PM} \times$ Fert $\times$ Mulch $\times \mathrm{cv}$ & NS & NS & NS & NS & NS \\
\hline \multicolumn{6}{|l|}{ Contrasts $^{\mathrm{v}}$} \\
\hline Feather vs. Fish & $<0.0001$ & NS & NS & $<0.0001$ & $<0.0001$ \\
\hline Low rate vs. High rate & 0.0295 & NS & 0.0474 & 0.0003 & $<0.0001$ \\
\hline Organic mulch vs. Weed mat & 0.0028 & 0.024 & NS & NS & NS \\
\hline
\end{tabular}

${ }^{\mathrm{z}}$ Seasonal weighted average calculated for each year and the mean presented here (2008-14).

${ }^{\mathrm{y}} \mathrm{TSS}=$ average total soluble solids for study period $(2008-14)$.

${ }^{\mathrm{x}}$ Means followed by the same letter are not significantly different as determined by analysis of variance using Tukey HSD test $(P>0.05)$.

${ }^{\text {w} A c t u a l ~} P$ values provided unless nonsignificant (Ns; $P>0.05$ ).

"Contrasts for fertilizer source ("Feather vs. Fish," averaged over nitrogen rate); N rate ("Low rate vs. High rate," averaged over source); the average response of sawdust and compost + sawdust mulch compared with weed mat ("Organic mulch vs. Weed mat"); and compost + sawdust mulch compared with sawdust mulch alone ("Compost vs. Sawdust").

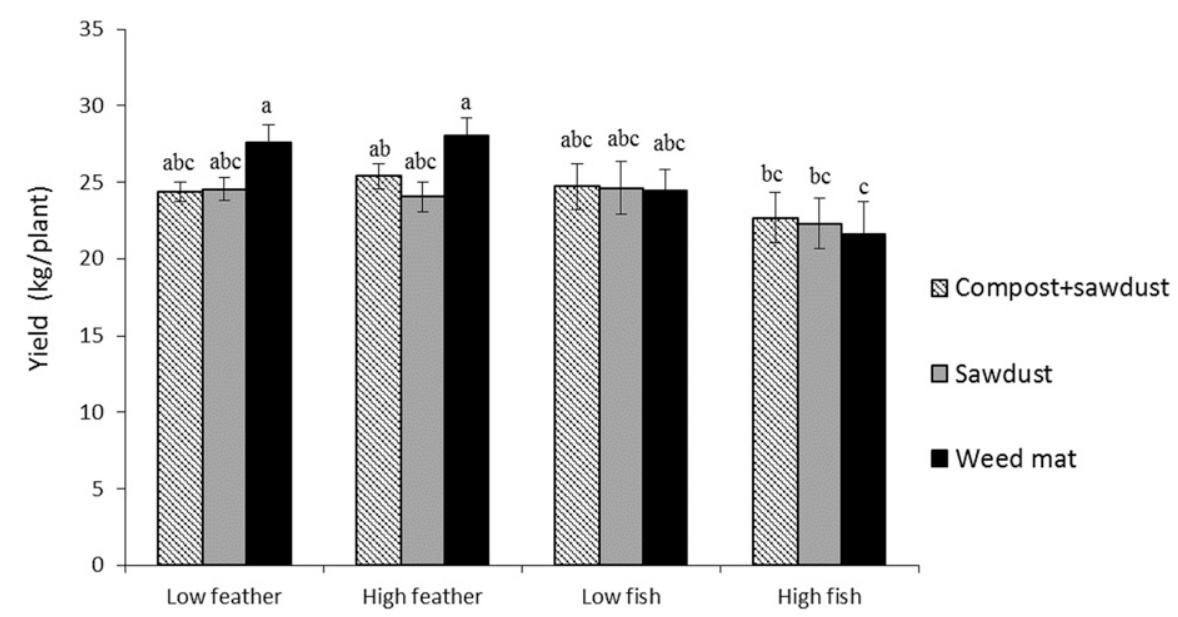

Fig. 4. Effect of organic mulch (compost + sawdust or sawdust only) or weed mat and fertilizing with low $\left(29-73 \mathrm{~kg} \cdot \mathrm{ha}^{-1} \mathrm{~N}\right.$ per year) or high $\left(57-140 \mathrm{~kg} \cdot \mathrm{ha}^{-1} \mathrm{~N}\right.$ per year) rates of feather meal or fish solubles on cumulative yield of northern highbush blueberry. The plants were grown in a certified organic planting in western Oregon and harvested from the second through the 10th growing season (2008-16). Means are averaged over a combination of two planting method (flat ground and raised beds) and two cultivar ('Duke' and 'Liberty') treatments. Error bars represent \pm 1 SE. Different letters above the bars in the graph indicate the means are significantly different at $P \leq 0.05$, as determined by LSMEANS.
Berry firmness was affected by year, fertilizer, mulch type, cultivar, and many interactions (Table 1). Over the study years, there was an interaction between fertilizer and planting method as well as fertilizer $\times$ mulch. During the first and second fruiting seasons (2008-09), berries were firmest when plants were fertilized with the high rate of fish and least firm when fertilized with the low rate of feather meal, regardless of planting method. The greater firmness found during the establishment years when fertilizing with the high rate of fish may have been related to the smaller berries produced in this treatment. On flat ground, fertilization with feather meal at either rate reduced firmness in 2011-12. By contrast, only plants fertilized with the low rate of feather meal had reduced firmness when grown on raised beds (2011-13 only) (data not shown). The pattern in berry firmness from 2008 to 2014 was quite similar across the fertilizer treatments, regardless of mulch type (Fig. 6). However, the difference between fish (firmer fruit) and 

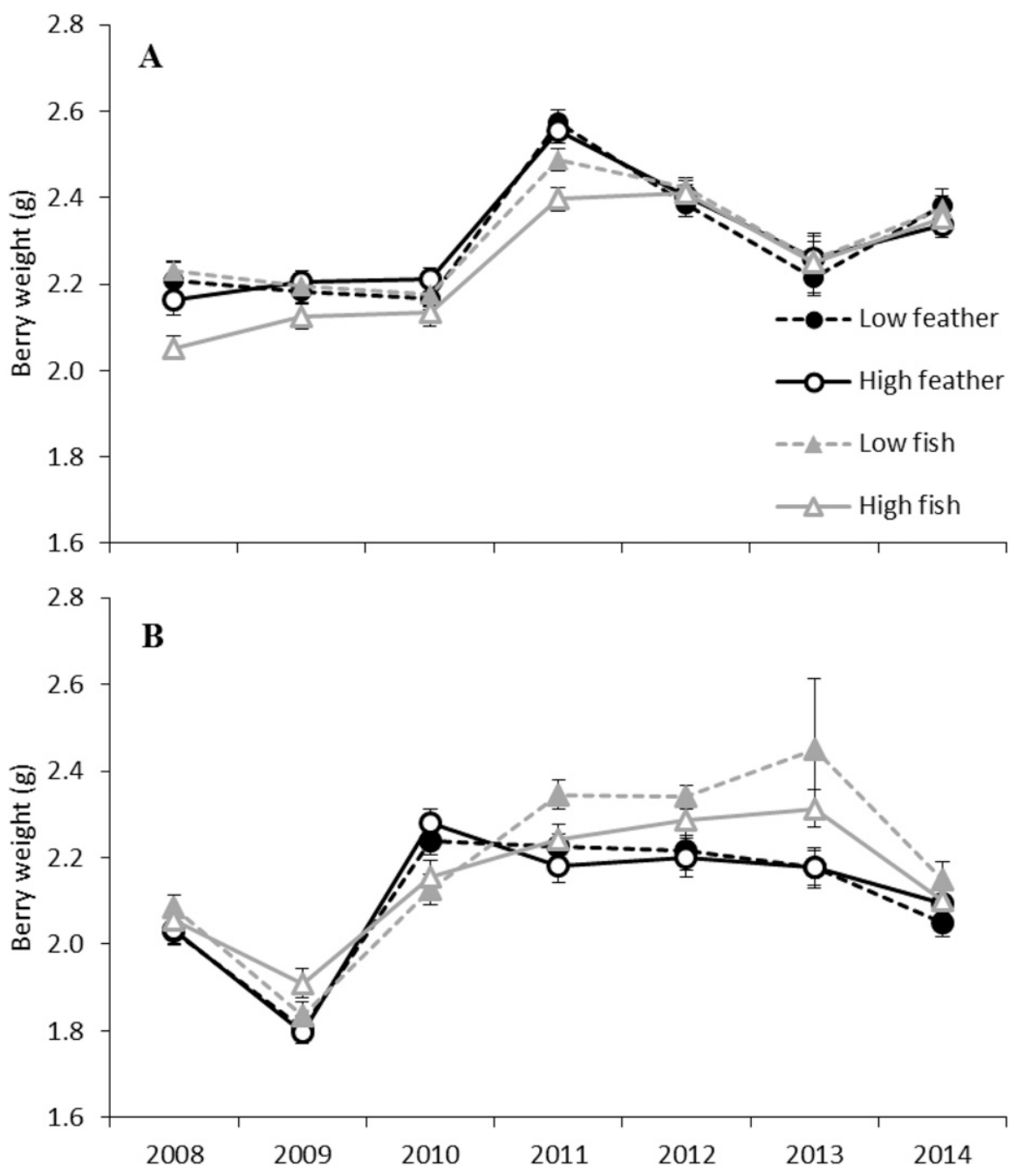

Fig. 5. Effect of fertilizing with low (29-73 $\mathrm{kg} \cdot \mathrm{ha}^{-1} \mathrm{~N}$ per year) or high $\left(57-140 \mathrm{~kg} \cdot \mathrm{ha}^{-1} \mathrm{~N}\right.$ per year) rates of feather meal or fish solubles on berry weight of (A) 'Duke' and (B) 'Liberty' northern highbush blueberry. The plants were grown in a certified organic planting in western Oregon and harvested from the second through the eighth growing season (2008-14). Means are averaged over a combination of two planting method (flat ground and raised beds) and three mulch (compost + sawdust, sawdust, and weed mat) treatments. Error bars represent $\pm 1 \mathrm{SE}$.

feather meal (least firm) was more pronounced for weed mat than for sawdust or compost + sawdust mulch when plants were young. Plants grown with compost + sawdust and fertilized with the high rate of fish also had firmer fruit than with the other fertilizer treatments from 2011 to 2013. When data were analyzed by year, plants fertilized with fish produced firmer fruit than with feather meal in five of the 7 years (data not shown). Also, fertilization with the higher rate of either product increased berry firmness compared with the low rate in six of the 7 years. The impact of mulch was inconsistent with weed mat decreasing berry firmness compared with the organic mulches (sawdust and compost + sawdust) in two of the 7 years, but increasing firmness in three of the 7 years. Adding compost to the mulch increased berry firmness in two of the 7 years relative to sawdust mulch alone (data not shown).

There was a fertilizer $\times$ cultivar interaction on the overall average berry firmness (2008-14) (Table 3) and throughout each of the weed mat to the sun compared with the mature plants in our study. Larco (2010) also noted a reduced net difference in soil temperature under weed mat and sawdust from 2007 to 2008 and reduced soil temperature fluctuations from day to night and with the seasons. Similar effects of plastic mulch or weed mat compared with a mulch of organic material on soil temperature has also been reported by others (Cox, 2009; Runham et al., 2000; Strik et al., 2006). Magee and Spiers (1995) found that white-on-black plastic polyethylene based mulches led to greater plant growth and yield than black plastic or black woven fabric mulches in southern highbush cultivars because of a decreased soil temperature in the more reflective mulches. During the early establishment years, we found that plants had a greater root dry weight when grown with sawdust (114 g/plant, on average) as compared with weed mat ( $87 \mathrm{~g} /$ plant) (Larco et al., 2013a) and had greater root production under sawdust than weed mat at the high fertilizer rate (Bryla et al., 2017). Larco (2010) reported a greater soil bulk density under weed mat as compared with sawdust mulch in 2008 and speculated that this led to reduced root growth under weed mat in early establishment. We will report on the longerterm impact of these mulches on root growth separately.

Raised beds required greater amounts of irrigation water (4424 L/plant, on average, from 2008 to 2014) to maintain similar levels of soil water content than did flat ground plantings (3843 L/plant; Table 4). Raised beds likely had lower holding water capacity than flat ground because of enhanced drainage (Magdoff and Van Es, 2010; Spiers, 1998; White, 2006). However, planting method may also have affected plant water requirements. Larco et al. (2013a) found that plants grown on raised beds had greater shoot to root ratios, and therefore, potentially use more water per unit root volume than plants grown in flat ground.

Plantings grown with weed mat required as much as 1072 to $1760 \mathrm{~L} /$ plant more cumulative irrigation than those grown with sawdust mulch on flat ground and raised beds, respectively (Table 4). Larco (2010) speculated that the increase in irrigation water requirement in 2007-08 was likely due to the higher soil temperature and canopy temperature with weed mat, as he measured no mulch effect on plant biomass in Oct. 2008. However, Larco et al. (2013a) did report an increased top (wood, leaves, and fruit) to root (crown and root) ratio in plants grown with weed mat in both cultivars. It is unknown at this time whether the mature plants in this trial differ in biomass allocation, perhaps accounting for continued differences in irrigation requirement.

A lower soil water content under weed mat relative to a wood chip mulch was also reported in organic apple production systems (Choi et al., 2011). In our study, the added irrigation required for the weed mat 

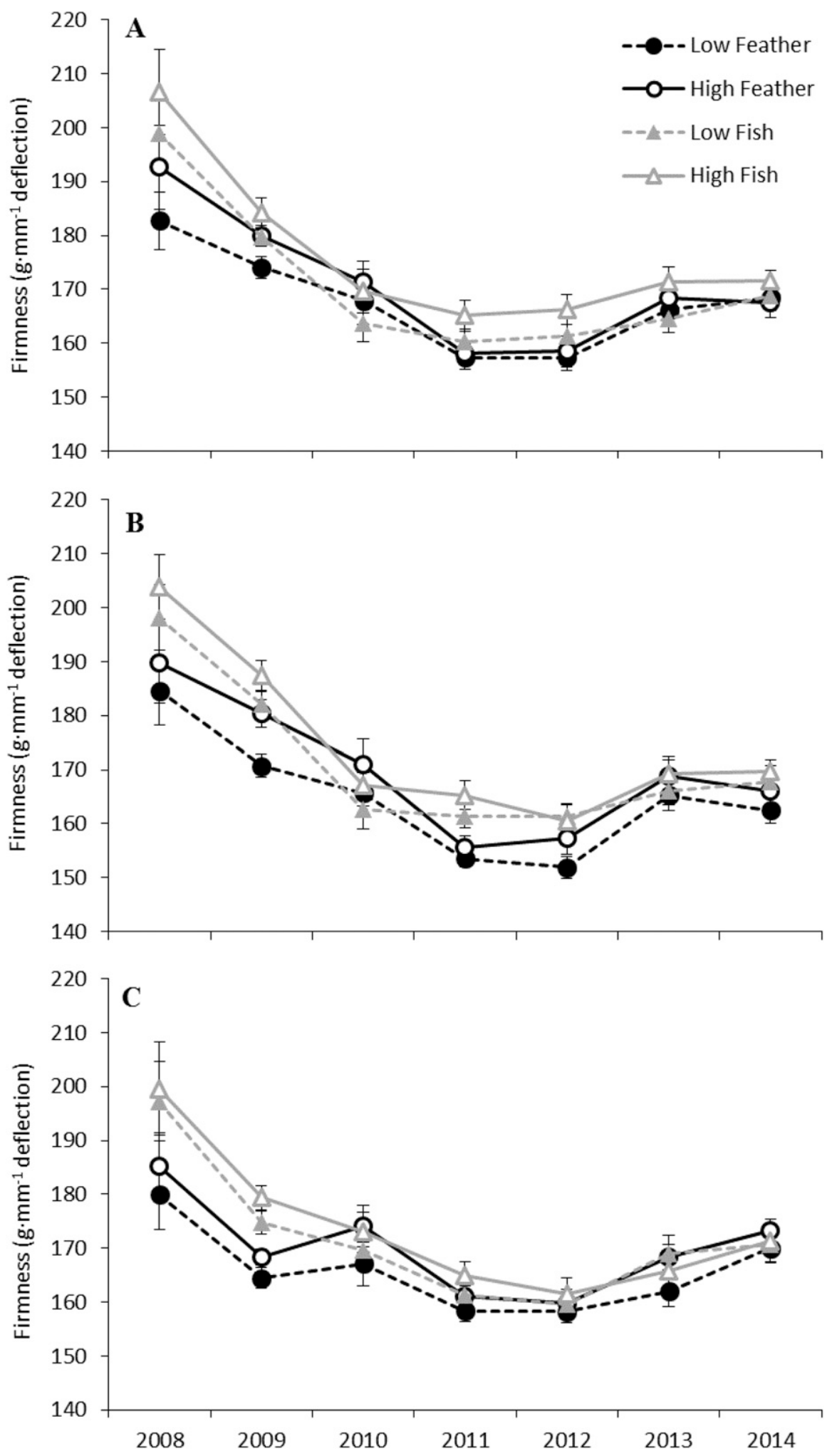

Fig. 6. Effect of fertilizing with low (29-73 kg.ha ${ }^{-1} \mathrm{~N}$ per year) or high $\left(57-140 \mathrm{~kg} \cdot \mathrm{ha} \mathrm{h}^{-1} \mathrm{~N}\right.$ per year) rates of feather meal or fish solubles on berry firmness (seasonal average) in northern highbush blueberry. The plants were mulched with (A) compost + sawdust, $(\mathbf{B})$ sawdust, or $(\mathbf{C})$ weed mat in a certified organic planting in western Oregon and harvested from the second through the eighth growing season (200814). Means are averaged over a combination of two planting method (flat ground and raised beds) and two cultivar ('Duke' and 'Liberty') treatments. Error bars represent \pm 1 SE.

mulch treatment may have affected nutrient uptake, as has been shown in apple (Neilsen et al., 2007) although we did irrigate all treatments to achieve a similar soil water likely roll off the surface of the mulch. Whereas this would not have been likely during most of the growing season as this is a period of very limited rainfall (data not shown) and plants were drip irrigated under the mulch, infiltration of rain water through the weed mat may have been an issue from October through May, when irrigation was not required but root growth was active (L. Valenzuela-Estrada, unpublished data). Changes in root growth patterns and possibly nutrient availability under the mulches studied may have affected plant and fruit nutrient status (Krewer et al., 2009; Lang et al., 2001; Larco et al., 2013b).

Soil and plant nutrient status. We have reported the impact of mulch on soil and plant nutrient status during planting establishment elsewhere (Larco et al., 2013b, 2014; Strik, 2016; Sullivan et al., 2015). Soil pH remained in the desirable range for blueberry $(4.5-5.5$; Hart et al., 2006) during the entire study period for all treatments (data not shown). However, the addition of the high-pH yard debris compost ( $\mathrm{pH}$ 7.3) under the sawdust mulch helped mitigate the decline in soil $\mathrm{pH}$ that occurred over the study from fertilization and increased soil organic matter content relative to the other mulch types (Sullivan et al., 2015). By contrast, when a high-pH onfarm compost ( $\mathrm{pH} 7.5$ ) was incorporated as an amendment before planting blueberry, there was a significant reduction in yield over 10 years (Strik et al., 2017). Differences in these responses may be due to the different application methods (mulch vs. amendment), but also the $\mathrm{pH}$ buffering capacity of the composts (Costello and Sullivan, 2014). In our study, use of yard debris compost as part of the mulch increased soil $\mathrm{K}$ during the establishment years (Larco et al., 2014; Sullivan et al., 2015), which may have long-term implications for plant nutrient status, especially for Mg (Eck, 1988; Krewer and Ruter, 2012). In a 2-year study, Burkhard et al. (2009) noted that the use of seafood waste compost increased soil $\mathrm{pH}$ and plant leaf $\mathrm{K}$ concentration. Although they found greater vigor and yield in the compost-mulched plots, the yield of the 5- to 7-year-old plants in their study was very low $(0.03-0.2 \mathrm{~kg} / \mathrm{plant})$. In our study, the addition of yard debris compost to the mulch had no significant effect on cumulative yield as compared with sawdust mulch alone (Table 3). We will report the long-term treatment effects on soil and plant nutrient status separately.

Overview. Blueberry plants in our study performed better ('Duke') or similarly ('Liberty') when fertilized at the lower rate of $\mathrm{N}$ than at the higher rate. Cultivar differences in performance with fertilizer $\mathrm{N}$ has also been reported for southern highbush blueberry in Florida (Wilber and Williamson, 2008). In our study, it was clear that plants did not require more fertilizer $\mathrm{N}$ than what was provided by the low rate of $\mathrm{N}$, either through the split application of feather meal or the seven equal applications of fish solubles that were fertigated. Other than the first year of 


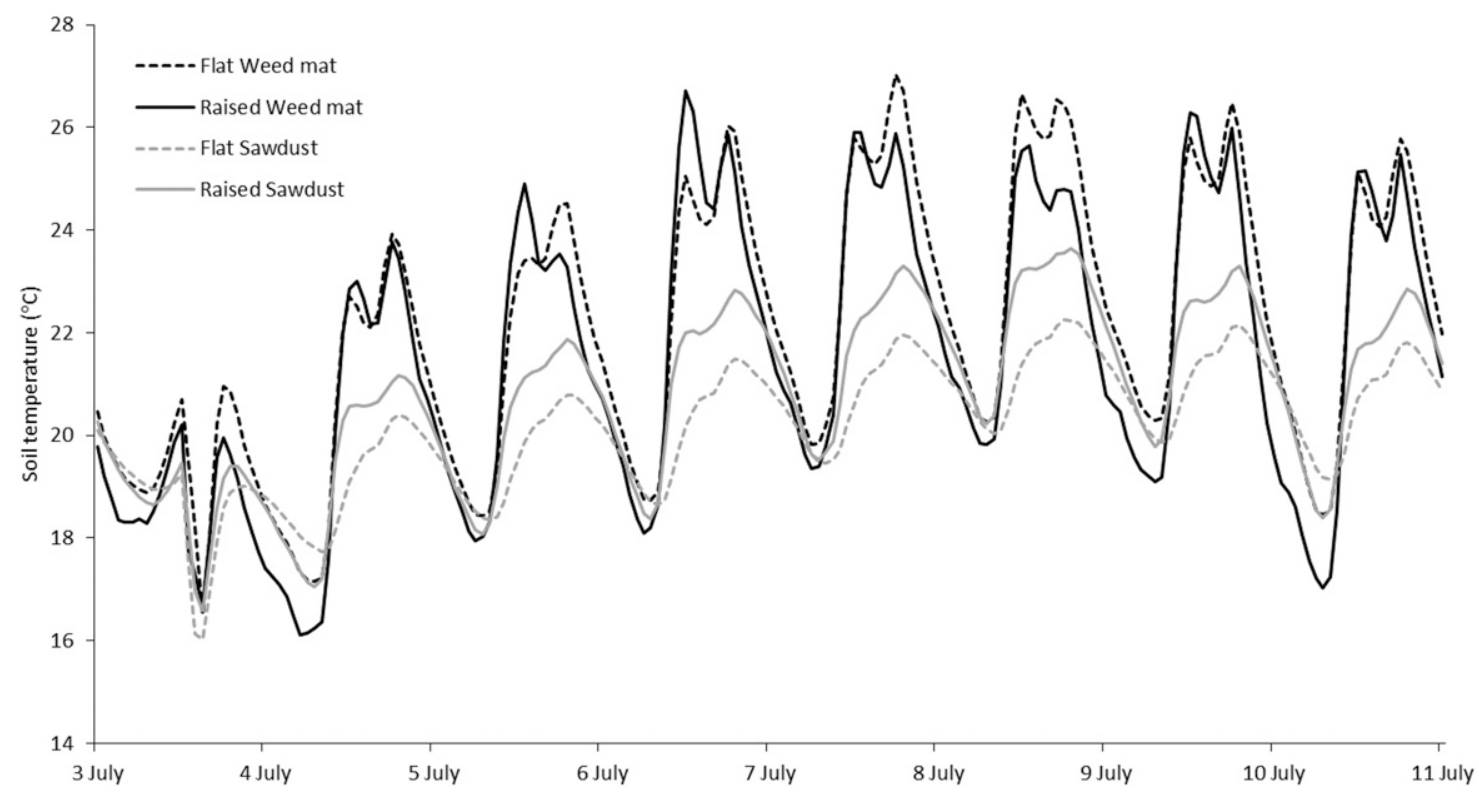

Fig. 7. Diurnal changes in soil temperature in flat ground and raised beds of northern highbush blueberry mulched with sawdust or weed mat. The planting was certified organic and located in western Oregon. Temperature was measured at a depth of $5 \mathrm{~cm}$ below the soil-mulch interface. Data are presented for 3-11 July 2014

Table 4. The total amount of irrigation water applied to northern highbush blueberry during the first 8 years after planting (2007-14). The plants were grown on flat ground or raised beds mulched with sawdust or weed mat in a certified organic planting in western Oregon.

\begin{tabular}{|c|c|c|c|c|c|c|c|c|c|}
\hline \multirow[b]{2}{*}{ Treatment } & \multicolumn{9}{|c|}{ Irrigation applied (L/plant) } \\
\hline & 2007 & 2008 & 2009 & 2010 & 2011 & 2012 & 2013 & 2014 & 2007-14 \\
\hline Sawdust & 247 & 69 & 242 & 480 & 517 & 561 & 506 & 685 & 3,307 \\
\hline Sawdust & 282 & 170 & 295 & 480 & 517 & 561 & 506 & 733 & 3,544 \\
\hline Weed mat & 651 & 465 & 287 & 556 & 685 & 730 & 952 & 977 & 5,304 \\
\hline
\end{tabular}

growth, when feather meal was applied too late (Larco et al., 2013a), the fertilizer $\mathrm{N}$ was apparently available when plants needed it in spring (Bañados, 2006; Bañados et al., 2012; Throop and Hanson, 1997). Any additional N provided by the "slow-release" $\mathrm{N}$ available in the yard debris compost (Gale et al., 2006; Sullivan et al., 2003) in the compost + sawdust mulch did not lead to an increase in yield. The added $\mathrm{N}$ in the compost was either not available at a time when plants require it (Hartz and Johnstone, 2006) or provided $\mathrm{N}$ above plant requirements. In conventional production, blueberry has not shown increased yield with higher rates of $\mathrm{N}$ above $50 \mathrm{~kg} \cdot \mathrm{ha}^{-1}$ (Bañados, 2006; Cummings, 1978; Ehret et al., 2014; Strik and Buller, 2014; White, 2006). Additional $\mathrm{N}$ fertilizer is recommended when using a mulch with a high $\mathrm{C}: \mathrm{N}$ ratio (e.g., sawdust compared with compost + sawdust or weed mat) (Hart et al., 2006; Williamson et al., 2006), as these mulches immobilize some of the fertilizer N (White, 2006). However, even the low rate of $\mathrm{N}$ was likely sufficient to account for any such immobilization. Although higher rates of $\mathrm{N}$ have reduced yield in some blueberry studies (Bañados et al., 2012; Eck, 1977), we did not find a reduced yield at the "high" rate, except when using fish solubles in 'Duke'. There may have been differences in availability or distribution of $\mathrm{N}$ in the root zone when fertilizing with feather meal or fish solubles. In addition, it is possible that other nutrients present in the fish fertilizer, particularly $\mathrm{K}$, may have reduced yield in 'Duke'.

Adding yard debris compost to the mulch increased weed presence likely because the more inert and drier top layer of sawdust eroded from wind or was disturbed when weeds were pulled by hand, and weed seeds that blew into the field quickly germinated in the exposed compost layer. The added weed management required in the compost + sawdust mulch thus made this treatment the least cost effective (especially as there was no benefit to yield) (Julian et al., 2012; Strik and Vance, 2017). Strik and Vance (2017) reported total weed management costs over the 2006-14 study period (including installation, replenishment, and weed-control products and labor) of $\$ 16,088$, $\$ 31,977$, and $\$ 45,656$ per hectare, for the weed mat, sawdust, and compost + sawdust mulch treatments, respectively. In 'Duke', even with no significant effect of mulch on cumulative yield, net returns would be greater when using weed mat mulch (Strik and Vance, 2017). In 'Liberty', weed mat increased cumulative yield $11 \%$ compared with the other mulches, further increasing net returns.
There may be some disadvantages to using weed mat mulch in the long-term, in addition to the higher irrigation requirement we measured in our study. We noted a greater presence of voles (Microtus spp.) under the weed mat, as noted by Granatstein and Mullinix (2008), but this did not reduce yield in our study. The reduction in soil organic matter that has been observed over time (Atucha et al., 2011; Choi et al., 2011; Larco et al., 2014; Neilsen et al., 2003; Sullivan et al., 2015) may be avoided by adding organic matter as a mulch, underneath the weed mat; this has looked promising in blueberry (Strik et al., 2017). Mulches have also had an effect on soil nutrient availability, microfauna, and nutrient fluxes (e.g., Forge et al., 2003; Goulart et al., 1997; Sullivan et al., 2015). We will address the long-term impact of mulches and fertilizer source on blueberry plant and soil nutrient status in a subsequent article.

When this study was initiated in 2006, the most common organic production system in this region was growing plants on raised beds with a sawdust mulch and fertilizing with a high rate of fish. In our study, the yield of 'Duke' and 'Liberty' during the mature production years (2014-16) was the equivalent of $8.9-12.3 \mathrm{t} \cdot \mathrm{ha}^{-1}$ and 
11.8-23.7 th ha ${ }^{-1}$, respectively, for this production system, depending on year. Growing plants on raised beds with weed mat instead of sawdust, yet still fertilizing with a high rate of fish (now common in our region) increased yield $16 \%$ in 'Duke', but had no effect on yield of 'Liberty'. However, when plants were fertilized with the high rate of feather meal, instead of fish, and were still grown with weed mat, yield increased by an additional $20 \%$ in 'Duke' (to 10.2-19.3 t.ha ${ }^{-1}$ ), but again had little effect in 'Liberty' (13.5-22.7 t.ha $\left.{ }^{-1}\right)$. These yields, particularly for the best-performing treatment combination in 'Duke', are similar to those observed in commercial conventional fields or organic farms using similar management practices (B. Strik, personal observation). They are also similar to what was reported for mature 'Duke' and 'Liberty' grown in differing amendment and mulching systems in long-term organic production (Strik et al., 2017). Tertuliano et al. (2012) reported similar yields of rabbiteye blueberry in Georgia when comparing organic and conventional production systems. However, they did note higher production costs for some of their organic treatments, as we noted for fertilizer costs above and for weed management in Strik and Vance (2017). It is clear that choice of the organic production system used in our region can have a significant impact on yield, production costs, and net returns.

\section{Literature Cited}

Atucha, A., I.A. Merwin, and M.G. Brown. 2011. Long-term effects of four groundcover management systems in an apple orchard. HortScience 46:1176-1183.

Bañados, M.P. 2006. Dry weight and ${ }^{15} \mathrm{~N}$-nitrogen and partitioning, growth, and development of young and mature blueberry plants. Ore. State. Univ., Corvallis, PhD Diss. 24 Aug. 2017. $<$ http://ir.library.oregonstate.edu/xmlui/handle/ 1957/9649>.

Bañados, M.P., B.C. Strik, D.R. Bryla, and T.L. Righetti. 2012. Response of highbush blueberry to nitrogen fertilizer during field establishment. I. Accumulation and allocation of fertilizer nitrogen and biomass. HortScience 47:648-655.

Bary, A.I., C.G. Cogger, and D.M. Sullivan. 2016. Fertilizing with manure and other organic amendments. Washington State University Extension. PNW 533 (revised).

Bryla, D.R. and R.G. Linderman. 2007. Implications of irrigation method and amount of water application on Phytophthora and Pythium infection and severity of root rot in highbush blueberry. HortScience 42:14631467.

Bryla, D.R. and B.C. Strik. 2007. Effects of cultivar and plant spacing on the seasonal water requirements of highbush blueberry. J. Amer. Soc. Hort. Sci. 132:270-277.

Bryla, D.R., L.R. Valenzuela-Estrada, and O.L. Vargas. 2017. Root production, distribution, and turnover in conventional and organic northern highbush blueberry systems. Acta Hort. (In press).

Burkhard, N., D. Lynch, D. Percival, and M. Sharifi. 2009. Organic mulch impact on vegetation dynamics and productivity of highbush blueberry under organic production. HortScience 44:688-696.

Chandler, R.B. and E.C. Mason. 1942. The effect of mulches on soil moisture, soil temperature, and growth of blueberry plants. Proc. Amer. Soc. Hortic. Sci. 40:335-337.

Choi, H-S., C.R. Rom, and M. Gu. 2011. Plant performance, and seasonal soil and foliar nutrient variations in an organic apple orchard under four ground cover management systems. J. Amer. Pomol. Soc. 65:130-146.

Clark, J.R. and J.N. Moore. 1991. Southern highbush blueberry response to mulch. HortTechnology 1:52-54

Costello, R.C. and D.M. Sullivan. 2014. Determining the $\mathrm{pH}$ buffering capacity of compost via titration with dilute sulfuric acid. Waste Biomass Valor 5:505-513, doi: 10.1007/s12649013-9279-y.

Cox, J. 2009. Comparison of plastic weedmat and woodchip mulch on low chill blueberry soil in New South Wales, Australia. Acta Hort. 810:475-482.

Cummings, G.A. 1978. Plant and soil effects of fertilizer and lime applied to highbush blueberries. J. Amer. Soc. Hort. Sci. 103:302-305.

DeFrancesco, J., J.W. Pscheidt, and W. Yang. 2016. Blueberry pest management guide for the Willamette Valley. Oregon State Univ. Ext. Ser. Pub., EM 8538.

DeVetter, L.W., D. Granatstein, E. Kirby, and M. Brady. 2015. Opportunities and challenges of organic highbush blueberry production in Washington State. HortTechnology 25:796-804.

Echeverría, G.V., J.V. Cañumir, and S.G. Humberto. 2009. Postharvest behaviour of highbush blueberry fruits cv. O'Neal cultivated with different organic fertilization treatments. Chil. J. Agr. Res. 69:391-399.

Eck, P. 1977. Nitrogen requirements of the highbush blueberry, Vaccinium corymbosum L. J. Amer. Soc. Hort. Sci. 102:816-818.

Eck, P. 1988. Blueberry science. Rutgers Univ. Press, NewBrunswick, NJ. p. 135-169.

Ehret, D.L., B. Frey, T. Forge, T. Helmer, D.R. Bryla, and B.J. Zebarth. 2014. Effects of nitrogen rate and application method on early production and fruit quality in highbush blueberry. Can. J. Plant Sci. 94:1165-1179.

Fernandez-Salvador, J.A., B.C. Strik, and G.O. Stephenson. 2017. The organic blueberry industry in Oregon: Results of in-person, on-site interviews with growers in 2015. Acta Hort. (In press).

Forge, T.A., E. Hogue, G. Neilsen, and D. Neilsen. 2003. Effects of organic mulches on soil microfauna in the root zone of apple: Implication for nutrient fluxes and functional diversity of the soil food web. Appl. Soil Ecol. 22:39-54.

Gale, E.S., D.M. Sullivan, D. Hemphill, C.G. Cogger, A.I. Bary, and E.A. Myhre. 2006 Estimating plant-available nitrogen release from manures, composts, and specialty products. J. Environ. Qual. 35:2321-2332.

Goulart, B.L., K. Demchak, and W.Q. Yang. 1997. Effect of cultural practices on field grown 'Bluecrop' highbush blueberries, with emphasis on mycorrhizal infection levels. Acta Hort. 446:271-278.

Granatstein, D. and K. Mullinix. 2008. Mulching options for northwest organic and conventional orchards. HortScience 43:45-50.

Griggs, W.H. and H.A. Rollins. 1947. The effect of planting treatment and soil management systems on the production of cultivated blueberries. Proc. Amer. Soc. Hort. Sci. 49:213-218.

Hanson, E.J. 2006. Nitrogen nutrition of highbush blueberry. Acta Hort. 715:347-351.
Hart, J., B. Strik, L. White, and W. Yang. 2006. Nutrient management for blueberries in Oregon. Oregon State University Extension Service. EM 8918. 15 Dec. 2016. <http://ir. library.oregonstate.edu/xmlui/bitstream/handle/ 1957/20444/em8918.pdf>.

Hartz, T.K. and P.R. Johnstone. 2006. Nitrogen availability from high-nitrogen-containing organic fertilizers. HortTechnology 16:39-42.

Julian, J., B. Strik, E. Pond, and W. Yang. 2011b. Blueberry economics: The costs of establishing and producing organic blueberries in the Willamette Valley, Oregon. Oregon State Univ. Pub. AEB 0023. 5 May 2017. <http://arec. oregonstate.edu/oaeb/files/pdf/AEB0023.pdf>.

Julian, J., B. Strik, and W. Yang. 2011a. Blueberry economics: The costs of establishing and producing blueberries in the Willamette Valley, Oregon. AEB 0022. 5 May 2017. <http://arec oregonstate.edu/oaeb/files/pdf/AEB0022.pdf>.

Julian, J.W., B.C. Strik, H.O. Larco, D.R. Bryla, and D.M. Sullivan. 2012. Costs of establishing organic northern highbush blueberry: Impacts of planting method, fertilization, and mulch type. HortScience 47:1-8.

Karp, K., M. Noormets, M. Starast, and T. Paal. 2006. The influence of mulching on nutrition and yield of 'Northblue' blueberry. Acta Hort. 715:301-305.

Kozinski, B. 2006. Influence of mulching and nitrogen fertilization rate on growth and yield of highbush blueberry. Acta Hort. 715:231235.

Krewer, G. and J. Ruter. 2012. Fertilizing bushes three years and older, p. 5. In: Fertilizing highbush blueberries in pine bark beds. Univ. Ga. Coop. Ext. Bul. 1291.

Krewer, G., M. Tertuliano, P. Andersen, O. Liburd, G. Fonsah, H. Serri, and B. Mullinix. 2009. Effect of mulches on the establishment of organically grown blueberries in Georgia. Acta Hort. 810:483-488.

Krewer, G. and R. Walker. 2006. Suggestions for organic blueberry production in Georgia. Univ. Ga. Ext. Fruit Publ. 00-1. 5 May 2017. <http:// www.smallfruits.org/Blueberries/production/ 06organicblues.pdf $>$.

Kuepper, G.L. and S. Diver. 2004. Blueberries: Organic production. ATTRA. 24 Aug. 2017. <www.attra. ncat.org $>$.

Lang, A., M.H. Behboudian, J. Kidd, and H. Brown. 2001. Mulch enhances apple fruit storage quality. Acta Hort. 557:433-521.

Larco, H.O. 2010. Effect of planting method, weed management, and fertilizer on plant growth and yield of newly established organic highbush blueberries. MS thesis, Oregon State Univ., Corvallis. 5 May 2017. <http://ir.library.oregonstate. edu/xmlui/handle/1957/18065>.

Larco, H., B.C. Strik, D.R. Bryla, and D.M. Sullivan. 2013a. Weed and fertilizer management practices for organic production of highbush blueberries-I. Early plant growth and biomass allocation. HortScience 48:12501261.

Larco, H., B.C. Strik, D.R. Bryla, and D.M. Sullivan. 2013b. Weed and fertilizer management practices for organic production of highbush blueberries-II. Impact on plant and soil nutrients, yield, and fruit quality during establishment. HortScience 48:1484-1495.

Larco, H., D.M. Sullivan, B. Strik, and D. Bryla. 2014. Mulch effects on highbush blueberry under organic management. Acta Hort. 1018:375-382.

Magdoff, F. and H. Van Es. 2010. Building soils for better crops. 3rd ed. Sustainable Agriculture Research and Extension (SARE). 5 May 2017. 
<http://www.sare.org/Learning-Center/Books/ Building-Soils-for-Better-Crops-3rd-Edition>.

Magee, J.B. and J.M. Spiers. 1995. Influence of mulching systems on yield and quality of southern highbush blueberries. In: R.E. Gough and R.F. Korcak (eds.). Blueberries: A century of research. Haworth Press, Inc., Binghamton, NY.

Neilsen, G.H., E.J. Houge, T. Forge, and D. Neilsen. 2003. Mulches and biosolids affect vigor, yield, and leaf nutrition of fertigated high density apple. HortScience 38:41-45.

Neilsen, G.H., E.J. Houge, T. Forge, D. Neilsen, and S. Kuchta. 2007. Nutritional implications of biosolids and paper mulch applications in high density apple orchards. Can. J. Plant Sci. 87:551-558.

Pritts, M.P., J.F. Hancock, and B.C. Strik. 1992. Highbush blueberry production guide. Northeastern Regional Agr. Eng. Serv., NRAES-55, Ithaca, NY.

Runham, S.R., S.J. Town, and J.C. Fitzpatrick. 2000. Evaluation over four seasons of a paper mulch used for weed control in vegetables. Acta Hort. 513:193-201.

Savage, E.F. 1942. Growth responses of blueberries under clean cultivation and various kinds of mulch materials. Proc. Amer. Soc. Hort. Sci. 40:335-337.

Sciarappa, W., S. Polavarapu, J. Barry, P. Oudemans, M. Ehlenfeldt, G. Pavlis, D. Polk, and R. Holdcraft. 2008. Developing an organic production system for highbush blueberry. HortScience 43:51-57.

Spiers, J.M. 1995. Substrate temperatures influence root and shoot growth of southern highbush and rabbiteye blueberries. HortScience 30:1029-1030.

Spiers, J.M. 1998. Establishment and early growth and yield of 'Gulfcoast' southern highbush blueberry. HortScience 33:1138-1140.

Strik, B. 2007. Horticultural practices of growing highbush blueberries in the ever-expanding U.S. and global scene. J. Amer. Pomol. Soc. 61:148-150.

Strik, B.C. 2014. Organic blueberry production systems - advances in research and industry. Acta Hort. 1017:257-267.

Strik, B.C. 2016. A review of optimal systems for organic production of blueberry and blackberry for fresh and processed markets in the northwestern United States. Sci. Hort. 208:92-103.

Strik, B., D. Brazelton, and R. Penhallegon. 1990. Grower's guide to pruning highbush blueberries.
Oregon State Univ. Extension Service Video, VTP002, Corvallis, OR, $22 \mathrm{~min}$.

Strik, B., C. Brun, M. Ahmedullah, A. Antonelli, L. Askam, D. Barney, P. Bristow, G. Fisher, J. Hart, D. Havens, R. Ingham, D. Haufman, R. Penhallegon, J. Psheidt, B. Scheer, C. Shanks, and R. Williams. 1993. Highbush blueberry production. Pacific Northwest Extension Bulletin 215. Oregon State Univ., Corvallis, OR.

Strik, B. and G. Buller. 2002. Improving yield and machine harvest efficiency of 'Bluecrop' through high-density planting and trellising. Acta Hort. 574:227-231.

Strik, B. and G. Buller. 2005. The impact of early cropping on subsequent growth and yield of highbush blueberry in the establishment years at two planting densities is cultivar dependent. HortScience 40:1998-2001.

Strik, B. and G. Buller. 2014. Nitrogen fertilization rate, sawdust mulch, and pre-plant incorporation of sawdust - Long-term impact on yield, fruit quality, and soil and plant nutrition in 'Ellliot'. Acta Hort. 1017:269-275.

Strik, B., T. Righetti, and H. Rempel. 2006. Black plastic mulch improved the uptake of ${ }^{15} \mathrm{~N}$ from inorganic fertilizer and organic prunings in summer-bearing red raspberry. HortScience 4:272-274.

Strik, B.C. and A. Vance. 2017. Weed management strategies in long-term organic blueberry production systems - Impact of mulch type and weed control methods on economics. Acta Hort. (In press).

Strik, B.C., A. Vance, and C.E. Finn. 2017. Northern highbush blueberry cultivars differed in yield and fruit quality in two organic production systems from planting to maturity. HortScience 52:844-851.

Sullivan, D.M., A.I. Bary, T.J. Nartea, E.A. Myrhe, C.G. Cogger, and S.C. Fransen. 2003. Nitrogen availability seven years after a high-rate food waste compost application. Compost Sci. Util. $11: 265-275$

Sullivan, D.M., D.R. Bryla, and R.C. Costello. 2014. Chemical characteristics of custom compost for highbush blueberry, p. 293-311. In: Z. He and H. Zhang (eds.). Applied manure and nutrient chemistry for sustainable agriculture and environment. Springer-Verlag, New York, NY.
Sullivan, D.M., B.C. Strik, and D. Bryla. 2015. Evaluation of alternative mulches for blueberry over five production seasons. Acta Hort. 1076:171-178.

Tertuliano, M., G. Krewer, J.E. Smith, K. Plattner, J. Clark, J. Jacobs, E. Andrews, D. Stanaland, P. Andersen, O. Liburd, E.G. Fonsah, and H. Scherm. 2012. Growing organic rabbiteye blueberries in Georgia, USA: Results of two multi-year field studies. Intl. J. Fruit Sci. 12:205-215.

Throop, P.A. and E.J. Hanson. 1997. Effect of application date on absorption of ${ }^{15}$ nitrogen by highbush blueberry. J. Amer. Soc. Hort. Sci. 122:422-426.

USDA-AMS-NOP. 2011. Program handbook: Guidance and instructions for accredited certifying agents \& certified operations. Winter edition, 2011.

U.S. Department of Agriculture. 2010. Table 6: Organic berries harvested from certified and exempt organic farms: 2008. In: Organic production survey (2008), 2007 census of agriculture. U.S. Dept. Agr., Natl. Agr. Statistical Serv., Washington, DC.

U.S. Department of Agriculture. 2014. Table 33: Berries: 2012 and 2007. In: 2012 census of agriculture. U.S. Dept. Agr., Natl. Agr. Statistical Serv., Washington, DC.

Valenzuela-Estrada, L.R., D.R. Bryla, D.M. Sullivan, and B.C. Strik. 2011. Organic blueberry research project: Roots. eOrganic. Kansas City, MO. 24 Aug. 2017. <http://www.extension.org/pages/ 32763/organic-blueberry-production-researchproject:-roots>.

White, L.D. 2006. The effect of pre-plant incorporation with sawdust, sawdust mulch, and nitrogen fertilizer rate on soil properties and nitrogen uptake and growth of 'Elliott' highbush blueberry. MS Thesis, Oregon State Univ., Corvallis. 24 Aug. 2017. <http://ir.library. oregonstate.edu/xmlui/bitstream/handle/1957/ 1363/WholeThesis.pdf? sequence $=1>$.

Wilber, W.L. and J.G. Williamson. 2008. Effects of fertilizer rate on growth and fruiting of containerized southern highbush blueberry. HortScience 43:143-145.

Williamson, J., G. Krewer, G. Pavlis, and C.M. Mainland. 2006. Blueberry soil management, nutrition and irrigation. In: N.F. Childers and P.M. Lyrene (eds.). Blueberries for growers, gardeners and promoters. E.O., Gainesville, FL. 